\title{
Abandonment, Ecological Assembly and Public Health Risks in Counter-Urbanizing Cities
}

\author{
Alexandra Gulachenski ${ }^{1}$, Bruno M. Ghersi ${ }^{1}$, Amy E. Lesen ${ }^{2}$ and Michael J. Blum ${ }^{1,2, *}$ \\ 1 Department of Ecology \& Evolutionary Biology, Tulane University, New Orleans, LA 70118, USA; \\ agulache@tulane.edu (A.G.); bghersi@tulane.edu (B.M.G.) \\ 2 Tulane-Xavier Center for Bioenvironmental Research, Tulane University, New Orleans, LA 70118, USA; \\ alesen@tulane.edu \\ * Correspondence: mjblum@tulane.edu; Tel.: +1-504-862-8295
}

Academic Editor: Tan Yigitcanlar

Received: 7 April 2016; Accepted: 11 May 2016; Published: 19 May 2016

\begin{abstract}
Urban landscapes can be transformed by widespread abandonment from population and economic decline. Ecological assembly, sometimes referred to as "greening", following abandonment can yield valuable ecosystem services, but also can pose a risk to public health. Abandonment can elevate zoonotic vector-borne disease risk by favoring the hyperabundance of commensal pests and pathogen vectors. Though greater biodiversity in abandoned areas can potentially dilute vector-borne pathogen transmission, "greening" can elevate transmission risk by increasing movement of pathogen vectors between fragmented areas and by giving rise to novel human-wildlife interfaces. Idled and derelict infrastructure can further elevate disease risk from vector-borne and water-borne pathogens, which can build up in stagnant and unprotected water that maintenance and routine use of delivery or sanitation systems would otherwise eliminate. Thus, framing "greening" as inherently positive could result in policies and actions that unintentionally exacerbate inequalities by elevating risks rather than delivering benefits. As counter-urbanism is neither a minor pattern of urban development, nor a short-term departure from urban growth, homeowner and municipal management of abandoned areas should account for potential hazards to reduce health risks. Further socioecological assessments of public health risks following abandonment could better ensure the resilience and well-being of communities in shrinking cities.
\end{abstract}

Keywords: coupled natural human ecosystem dynamics; ecosystem services; emerging infectious disease; dilution effect; biodiversity; environmental justice

\section{Introduction}

Counter-urbanizing landscapes can be transformed by widespread abandonment resulting from rapid economic and population decline [1,2]. Counter-urbanization has been increasing over the last 50 years, with approximately 370 cities worldwide of $\geqslant 100,000$ residents having now experienced population loss of more than 10\% [3]. Most instances of loss have occurred in developed countries. For example, there are more than 70 shrinking cities in Europe, and a comparable number (92) of counter-urbanizing cities are located in the United States (US) [4,5]. Although most cities encompass some vacant land and properties due to turnover of homeownership, counter-urbanizing cities exhibit much higher rates of abandonment and vacancy [6]. According to the 2010 Census, US cities with declining populations had a notably higher percentage of vacant properties than those experiencing population growth (Figure 1) [7]. 


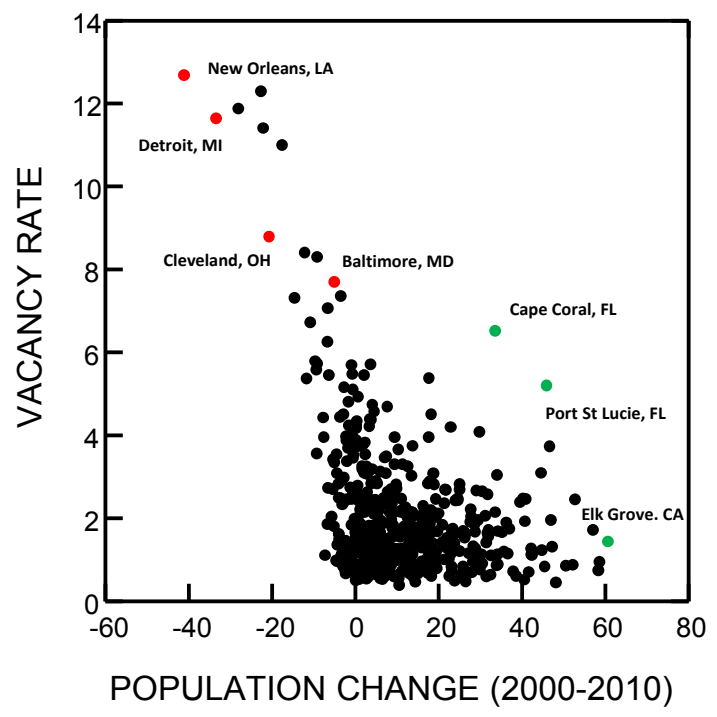

Figure 1. Percent Population Change and Abandonment in US Cities. The relationship between vacancy rate of private lots and human population change in 450 of the largest US cities (defined as census places, which only accounts for population size within city limits) by population size. Characteristic counter-urbanizing (red) and urbanizing cities (green) are highlighted [7].

Counter-urbanizing landscapes often bear the legacy of past habitation but are also shaped by ongoing municipal land management practices [8-10]. Though some features are widely shared-such as patchy mixtures of occupied and abandoned structures alongside the emergence of "ruderal" or "spontaneous" vegetation - counter-urbanizing landscapes do not necessarily follow parallel trajectories due to socioeconomic and cultural heterogeneity within and among cities [11,12]. For example, the diversity of tree assemblages has increased in the Lower Ninth Ward of New Orleans (LA, US) due to the rise of invasive species following flooding disturbance and limited landscape management triggered by Hurricane Katrina [9]. However, in neighboring St. Bernard Parish (LA, US), which was also redefined by precipitous population loss, regular and systematic maintenance of abandoned lots has inhibited the emergence of opportunistic species [9]. Evidence of contrasts elsewhere emphasizes how implementation of assertive public policy can mediate socioecological outcomes of counter-urbanization [13].

The structure of counter-urbanizing landscapes differ from those that arise from urbanization and suburbanization such as concentric ring and core-periphery configurations [14-16]. Nonetheless, counter-urbanization is still often framed by prevailing conceptual models that portray ecosystem outcomes as uniformly distributed along gradients of human population density [14,17]. Features of counter-urbanizing landscapes (Figure 2), like abrupt shifts between habitation and abandonment, more closely correspond to predictions of hierarchical patch dynamic models. Patch dynamic theory, which accounts for non-linear heterogeneity [18-20], builds on the theory of island biogeography to address and quantify interactions across habitat and ecosystem mosaics [21]. In human-dominated systems like cities, patches can be defined biologically (i.e., species assemblages), physically (i.e., soils, topography and built structures) and socially (i.e., the spatial and temporal clustering of human activities) [21]. Patches also can be defined according to the pace of change over time, ranging from rapid progressions (e.g., rush hour traffic) to more measured developments (e.g., neighborhood recovery) that influence ecosystem structure and function [22]. Counter-urbanization also conforms to transdisciplinary models of coupled human and natural system dynamics that consider ecological and sociocultural processes to be reciprocal and inextricably linked [23]. This is well illustrated by the often disproportionate distribution of abandoned and vacant lots in low-income areas of counter-urbanizing cities (Figure 2) [24], which can be reinforced by discriminatory public policies that stymy economic (re)development $[9,25]$. 

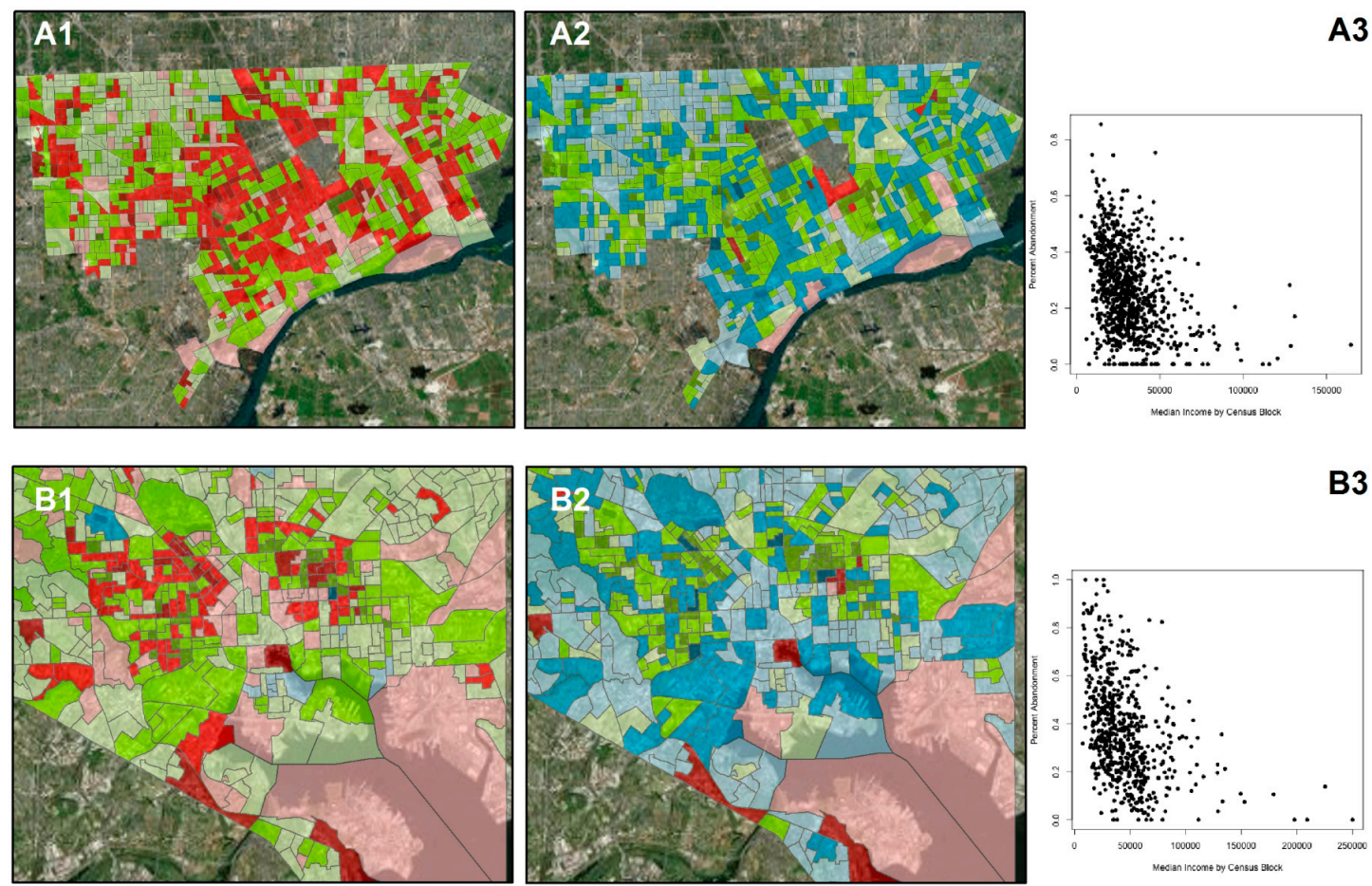

B3
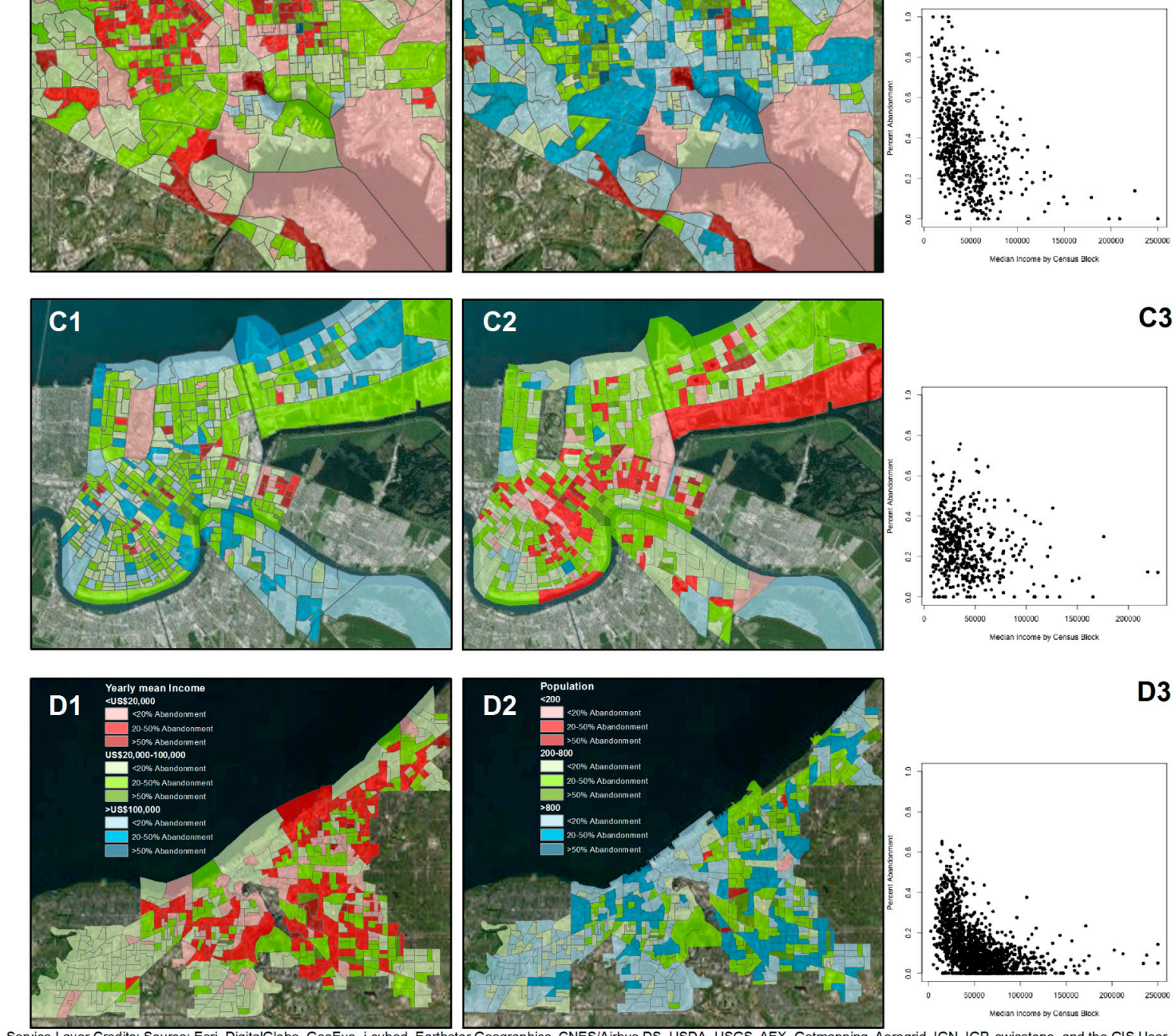

C3

D3

Figure 2. Abandonment, Income and Population Densities in Counter-urbanizing US Cities. The relationship between housing abandonment and census block median income (A-D1 and A-D3) and between abandonment and population density (A-D2) in four exemplar counter-urbanizing US cities: (A1-3) Detroit (MI, US); (B1-3) Baltimore (MD, US); (C1-3) New Orleans (LA, US); (D1-3) Cleveland (OH, US).

Qualities of counter-urbanization also differ from conditions in urban and suburban areas. Even features held in common may exhibit distinct qualities. "Green" landscape elements are often highly valued in urbanizing areas, for example, but are not always beneficial to remaining residents in 
counter-urbanizing areas (Figure 2) [1,2,6,26]. Increases in greenspace due to abandonment can yield an array of ecosystem disservices and hazards. For instance, "greening" is not necessarily favorable if communities are dominated by species that harbor commensal pests [27]. "Greening" may also be hazardous to human health by encouraging disease transmission at novel human-wildlife interfaces and through deterioration of built infrastructure [28,29]. Accordingly, greenspace should be viewed as more than "service-providing units" when assessing outcomes arising from population loss and abandonment [30]. This is of particular concern in low-income and vulnerable communities where abandonment is often disproportionately concentrated (Figure 2).

Despite increasing interest in urban resilience and counter-urbanization [1,6], the socioecology of population de-concentration and abandonment is not well understood [10]. In particular, little is known about the conditions that govern communicable disease risk as counter-urbanization unfolds [31]. Examining the socioecological processes associated with counter-urbanization and potential linkages with vector-borne and water-borne disease [32] can engender more effective policies to ensure community resilience and well-being. As a first step towards this goal, here we pose and address three related questions: (1) How does counter-urbanization differ from suburbanization and urbanization? (2) How is abandonment different from other forms of urban greening? (3) How can abandonment influence communicable disease risk? We address these questions by first contrasting counter-urban landscapes with urban and suburban landscapes. We then assess the configuration, socioecological composition, and perception of greenspace resulting from abandonment. Lastly, we consider how ecological, physiographic and infrastructure conditions arising from abandonment can influence exposure risk to zoonotic and water-borne pathogens.

\section{Counter-Urbanization: Legacies, form, Ecosystem Structure and (Dis)services}

Human settlement and associated land use change (i.e., changes in patch size and infrastructure development) can drive urban ecosystem dynamics. The development of a neighborhood, for instance, can interrupt bird nesting patterns and the construction of greenways along roads can facilitate dispersal by increasing connectivity [12,33-35]. By extension, human demographic changes and the associated balance of space and resources can govern variation in patch structure, landscape connectivity, and biodiversity in cities $[12,36,37]$. Associated aspects of human demography distinguish counter-urbanization from other widely recognized urban forms, including urbanization and suburbanization [34]. For example, a decrease in population density accompanying land abandonment can increase ecosystem connectivity in counter-urban areas, which can subsequently increase species diversity through the immigration of invasive and disturbance tolerant species. This is well illustrated by spider communities across abandoned lands in Cleveland (OH, US), which have become dominated by a diverse array of disturbance-tolerant genera and highly dispersive colonizers [38]. In contrast, reductions in human population density in suburban areas are often accompanied by increased land development, which tends to lower species diversity by producing fragmentation and edge effects [34]. Other distinctive features of landscape legacies, ecosystem structure, and community assembly further distinguish counter-urbanization from other urban forms.

\subsection{Landscape Legacies and Urban Forms}

The nature and influence of landscape legacies on vital ecosystem processes differ among urban forms $[15,19]$. Legacies arise from the history of land use and land cover change that alter patch configurations (e.g., remnant greenspace, parks, buildings) and related ecosystem processes. Spatial variability in the orientation of buildings and artificial surfaces, for example, can dictate the physical space available for vegetation and habitat along with associated ecosystem services like water storage and temperature moderation [8,39]. Fragmented greenspace and impervious cover (i.e., pavement, impenetrable material, compacted soil) are emblematic of densely populated urbanizing areas [40]. Natural variability (e.g., hydrological cycles) is often more highly constrained in urban areas through topographic modification [12]. Suburban areas on urban fringes, which are characterized 
by more widely dispersed human populations, often exhibit less impervious land cover with larger patch fragments and habitat corridors [36] that correspond to highly managed greenspaces (e.g., lawns, gardens, and parks) embedded within remnant agricultural and forested lands as a consequence of encroachment. Counter-urbanizing areas exhibit some superficial similarities with suburban areas, but suburban and counter-urban landscapes follow contrasting trajectories. For instance, both suburban and counter-urban areas can be dominated by open areas interspersed with built infrastructure. However, unlike suburban areas, counter-urban conditions are largely attributable to the cessation or reversal of intensive land use in urban areas, which is followed by infrastructure degeneration and growing aggregations of abandoned or vacant property $[1,8]$.

\subsection{Ecosystem Structure, Function, and (Dis)Services}

Shifts in human demography also can shape the structure and function of urban ecosystems by governing habitat and resource availability [41,42]. Human settlement, along with regional physiogeographic factors, can determine the spatial configuration, or morphology, of an urban ecosystem [36]. Though cities are often portrayed as homogeneous environments, variation in human settlement can translate to regional and system-wide differences in urban morphology. Urbanizing areas, for example, are generally associated with an overall decrease in tree canopy cover [12]. Counter-urban and suburban areas exhibit notable similarities at a regional scale, including the configuration of human-wildland interfaces. Juxtapositions formed through suburban development of forested and agricultural areas tend to increase human-wildlife interfaces [43], as do mosaics of occupancy and abandonment in counter-urban areas [9]. At the patch level, however, distinct and variable conditions are created by different landscape legacies and trajectories [44]. Block-by-block, ecosystem processes can differ among suburban and counter-urban areas that exhibit parallel morphologies. Comparisons in eastern Germany illustrate how a block of greenspace can vary greatly in vegetation structure and associated functions, such as nutrient cycling [45], among areas experiencing population growth or decline [37].

By influencing ecosystem structure and function, urban morphology can determine the distribution and availability of ecosystem services and disservices (hereafter referred to as "ecosystem (dis)services"). For example, tree canopy cover-which is widely viewed as an amenity or source of ecosystem services [46,47]—can be unevenly distributed within cities according to the balance of pervious and impervious surfaces, parcel size, and population density [48-52]. A vegetation survey in New York City (NY, US) found, for instance, that public rights of way and residential areas had a higher percentage of tree canopy cover than vacant lands [35]. Additionally, the distribution of tree canopy cover can reflect prevailing patterns of sociopolitical inequality and discriminatory land management policies [48,49,51]. Patterns of inequality are not always readily evident, however, because of temporal lags and discontinuities (e.g., changes in tree canopy often unfold over a longer period of time than shifts in population demography). Legacies therefore may have as much influence on vegetation characteristics as present socioeconomic status or ongoing land management in a given area of interest [35]. This is well illustrated by the distribution of tree canopy cover in Baltimore (MD, US), which is largely associated with higher socioeconomic status, except for some lower income neighborhoods where higher canopy cover is attributable to legacies of decades-old plantings [53]. By extension, urban morphology can affect related ecosystem (dis)services, including amenities like carbon sequestration, harborage of more diverse ecological communities, and mitigation of air pollutants and the heat island effect. Consideration of the heat island effect illustrates the extent to which the prevailing urban morphology governs ecosystem (dis)services. Highly-urbanized areas with dense populations are generally hotter and exhibit a reduced temperature range due to elevated night-time minimum temperatures [54]. Phoenix (AZ, US) exemplifies this condition; temperature in the metropolitan area has increased with population growth. Baltimore, on the other hand, has experienced declining temperatures accompanying a decline in population, as well as infrastructure loss and a higher density of greenspace [54]. 
The balance of ecosystem (dis)services also can be contingent on the maintenance and use of municipal infrastructure, like storm water and drinking water systems, which can have considerable influence on the socioecological structure of a city. Aging water infrastructure and sewer systems in older cities can intensify runoff and contaminant loads (e.g., through combined sewer overflow events) [55]. Some cities have taken steps to manage runoff and improve drainage. For example "off-lining" runoff with greenspace (i.e., green infrastructure) has been pursued to increase storm water retention and decrease overflow events [6]. Socioeconomic constraints can, however, hinder improvement and implementation of innovative management strategies, especially in communities experiencing a declining tax base due to population loss, as in St. Bernard Parish (LA, US) and Flint (MI, US) [25].

\section{Counter-Urbanization and Abandonment}

Abandonment is a manifestation of counter-urbanization. Abandoned areas are often (but not always) fully released from human intervention [56]. Abandonment is by no means a phenomenon restricted to counter-urban areas. Parallels can be found elsewhere, such as old fields in fallow farmland and transitional zones in urbanizing areas $[57,58]$. To some degree, nearly all cities harbor isolated patches of abandonment, but counter-urbanizing cities encompass broader mosaics of abandonment bearing the legacy of past use [8]. Abandonment is a landscape transformation that may also be sustained by a declining tax-base and limited potential to attract financial investment $[8,24]$. Thus far, few studies have examined abandonment resulting from counter-urbanization, but comparisons of planned and un-planned greenspaces suggest that release from human intervention does not necessarily restore ecosystem functioning or services [59]. Intentional "re-greening" of abandoned areas also often falls short of desired outcomes; a meta-analysis suggests that restoration typically only results in modest increases in desirable biodiversity (e.g., $~ 45 \%$ ) and associated ecosystem services (e.g., 25\%) [60]. Similar inferences have been drawn from assessments of ecological conditions associated with farmland abandonment and isolated urban vacancies $[8,61]$.

\subsection{Urban Versus Counter-Urban "Greening"}

A spectrum of managed-to-unmanaged greenspace can be found in most cities. Urbanizing areas tend to be dominated, however, by managed greenspace, which comes in a variety of forms including gardens, parks, green corridors like roadside vegetation as well as sidewalk plantings and trees, golf courses, sports grounds, and green roofs. Counter-urban areas, in contrast, harbor more unmanaged and abandoned greenspaces, which include vacant lots, brownfields, unmaintained infrastructure, demolition sites, as well as remnant areas peripheral to woodlands and waterways.

"Greening" is often cast in a favorable light in public policy and urban planning [29], with a focus on valued services gained by nearby residents and communities $[26,29,55]$. Managed greenspaces (e.g., gardens, parks, street trees) can deliver a rich portfolio of ecosystem services including storm water management, urban agriculture, and psychological benefits, as well as elevating the diversity of valued plants and arthropods [12,26]. Though often framed otherwise, increases in greenspace do not always result in favorable outcomes, particularly in counter-urbanizing areas with concentrations of abandonment $[1,2,6,26]$. "Greening" can yield an array of ecosystem disservices. Unmaintained vegetation can harbor commensal pests, for instance, including species that function as pathogen vectors or reservoirs [9,55]. Nonetheless, there is a persistent tendency for emphasis to be placed on measures that sound favorable (e.g., the diversity of vacant lots is generally greater than managed greenspaces) without appropriate sociocultural context [9]. For example, neighborhoods in New Orleans that were severely flooded following Hurricane Katrina harbor more diverse plant and vertebrate communities, but the dominance of ruderal plants and prevalence of feral animals has sparked public safety and health concerns [9]. Thus framing "greening" as inherently positive in urban management and city planning [29] could result in actions that unintentionally exacerbate inequalities by elevating risks rather than delivering benefits [37]. 


\subsection{Configurations and Perceptions of Abandonment}

Patterns of abandonment may differ depending on the factors leading to population or economic decline in counter-urbanizing cities, but common configurations include the doughnut pattern as observed in US cities. This pattern reflects densely populated city centers hollowing out as people move elsewhere (Figure 2), leaving the city center more sparsely populated and characterized by brownfields and vacant lots [62]. On the other hand, many shrinking cities in eastern Europe exhibit a mosaic pattern, where abandonment is more widespread due to uneven vacancy, emigration, and targeted demolition [37]. Positive feedbacks can undergird or intensify both configurations, as abandonment can attract illegal activities (e.g., waste disposal) that elicit unfavorable perceptions [62]. The visual aesthetic of unmanaged emergent vegetation can, by itself, create a social stigma in neighborhoods with concentrations of abandonment, depressing property values and reinforcing capital disinvestment $[29,63,64]$. Indeed, some consider widespread abandonment to be symptomatic of feedbacks between weak real estate prices and municipal land management practices that are fueled by social stigma $[8,9,49]$.

\subsection{Abandonment and Assembly}

Abandonment spurs dynamic assembly of urban plant and animal communities that can yield novel or alternate states of equilibrium [65]. Abandonment has been characterized as a phase in a cyclical progression of occupation, decline and reoccupation [66], but lags and legacies can interact with ongoing management to produce non-linear outcomes. Legacies and intermittent or regularly recurring disturbance from management interventions (e.g., mowing) can, however, prevent communities from achieving equilibrium [67]. Disturbances that generate or act on abandoned areas also can be acutely punctuated or unfold over decades. For example, a catastrophic disturbance (e.g., a flood, earthquake, or hurricane) can transpire over a matter of minutes to days, whereas subsequent recovery typically proceeds over years to decades. Similarly, steady economic decline can result in a slow progression of land use change.

Though species abundance and community composition can vary greatly from patch to patch within cities [56], regional differences in ecological communities are readily evident between managed and unmanaged lands. Managed lands reflect "facilitated assembly", which is intentional manipulation of species occurrence and abundance via localized management for food production, gardening, and other aesthetic outcomes [44], whereas unmanaged lands reflect "self-assembly" [17,62]. Urban areas, which generally harbor lower diversity, are predominantly characterized by facilitated assembly of highly discontinuous, ornamental and non-native plant communities with little to no grassland components [68]. Suburban areas are characterized by facilitated assembly of curated ornamental plants and grasslands spanning larger parcels of private land bordering wildlands. Communities in counter-urban areas are more often a product of self-assembly. Abandoned areas typically exhibit higher spatial and temporal variability as a consequence of rapid turnover of curated human-maintained plant species following release from management [56]. Abandoned areas often progress through stages that initially resemble grasslands, and depending on geography and management regime, proceed to resemble secondary forest dominated by opportunistic and invasive species $[6,9]$.

The close proximity and sometimes-coincident footprints of counter-urban ecological and societal communities increase the likelihood that interactions influence assembly. Assembly in counter-urban landscapes can thus also be viewed as a coupled dynamic, with outcomes (e.g., diversity) being contingent on site legacy, shared responses to common drivers, and interactions. Coupled assembly can involve both stochastic and deterministic processes such as competition, facilitation, initial conditions, evolutionary history, and resource availability [41,42,69-75]. For example, a catastrophic disturbance (e.g., flooding) can establish initial conditions with subsequent community formation shaped by interactions, such as cultivation of species that provide valued services (e.g., reforestation to moderate heat exposure). Coupled assembly therefore can be viewed as an operational form of socioecological 
transformation, where "ecological" and "societal" factors are reciprocally related [76], and where humans are agents of change [34,77].

Following a punctuated disturbance or the onset of progressive disturbance, assembly in an abandoned area typically commences with demolition or release from management. Assembly can be shaped by the removal of built structures and deposition of waste, which can affect microclimate, local topography and patch qualities like soil composition and hydrology [78]. Management intensity, patch size and configuration, resource availability, regional diversity, and vagility of assembling species can further mediate community formation [79]. Plant community composition, diversity, and productivity in vacant lots across Baltimore, for example, can depend as much on whether the lot fell within the footprint of a demolished building as natural mechanisms like species area relationships and dispersal [67].

Despite the range of factors shaping assembly, it is possible to identify a few broadly generalizable features of community composition in abandoned areas. Abandoned areas like brownfields and remnant private yards typically harbor greater plant species richness [62,79], and exhibit greater site-to-site variability than managed areas $[17,62,67,80]$. Though invasive and pest species are often dominant, abandoned areas also can provide habitat for rare species [9,81]. Invertebrate and vertebrate community composition often reflect underlying ecosystem structure and plant community composition [81] that dictate the distribution and availability of habitat and other vital resources [61]. For example, plant diversity can influence the abundance of natural enemies (i.e., parasites, predators) $[79,80,82]$. This is well illustrated in patterns of urban arthropod diversity $[56,83]$. Landscape modifications that govern fragmentation and patch mosaics (e.g., age, size and configuration) can further alter faunal communities by changing behavioral and ecological interactions including ease of movement, interspecific competition and habitat preferences [56,84-86]. Deer densities, for instance, can be elevated by greater human-wildland interfaces that provide greater shelter and food sources and reduced predation pressure [12].

\subsection{Abandonment and Infrastructure Decline}

Population loss can upset the balance of municipal services and revenue [8]. Similar to cities experiencing rapid population gain, cities experiencing population decline suffer mismatches between population size and capacity, which may leave residents without basic services [8]. Like rapid urbanization, counter-urbanization can reduce the efficiency of scale and availability of tax-reliant services like policing, fire protection and infrastructure maintenance. Unlike rapid urbanization, counter-urbanization results in an excess of unmaintained or idled infrastructure due to the patchy distribution of residency [8]. Though services that involve soft costs (e.g., staffing) can be scaled back to match demand, it is challenging to disinvest in or decommission infrastructure that was built to service a larger population [8]. Sidewalks, streets, and other service-providing infrastructure like municipal storm sewers, sanitary sewers and water supply lines are sunk capital assets that cannot be readily withdrawn or re-scaled to reflect a redistributed or smaller population [8]. With a declining tax-base, counter-urbanizing cities may struggle to support unused infrastructure or once-private infrastructure that entered the public domain due to abandonment [87]. Eventual outcomes include accumulated public expense, higher utility fees, and deteriorating infrastructure. This can, in turn, yield outcomes like reduced water quality that lead to public health concerns.

Neglect or limited use of service-providing infrastructure can influence ecological communities and the balance of ecosystem (dis)services in counter-urban areas. Idled or degraded infrastructure in abandoned areas-including areas with managed landscapes that have experienced population loss-can increase the availability of habitat supporting commensal pests and pathogen vectors $[84,85]$. For example, standing water that collects in container habitats, like tires and poorly drained depressions, can support mosquito larvae [85]. In areas of New Orleans that experienced rapid population loss following Hurricane Katrina, abandoned swimming pools also greatly increased the presence of mosquito larvae $[84,85]$. Illegal dumping of litter and food waste that often accompanies 
abandoned infrastructure can similarly sustain larger populations of other pests including pathogen vectors like rats, which can elevate disease transmission [86]. Additionally, neglect or limited use of water and sewage systems can create conditions favorable to the build-up of water-borne contaminant loads and pathogens $[88,89]$.

\section{Counter-Urbanization, Abandonment and Human Health}

Though it is becoming well understood that socioecological factors can govern disease transmission in cities [90], little work has been done to determine how counter-urbanization influences exposure risk. Inferences can be drawn, however, from work done on zoonotic and water-borne infectious disease dynamics in urban areas undergoing relevant demographic transitions (Figure 3). More than $75 \%$ of emerging infectious diseases (EID) - including those that prevail in cities—are vector-borne and zoonotic in origin [90]. EIDs frequently arise as a consequence of spillover from natural host-pathogen cycles, and often involve pathogens that have recently increased in geographic or host range, abundance and intensity (e.g., malaria, dengue, etc.) [90]. Vector-borne zoonotic diseases involve an intermediate species that harbors and transmits a pathogen to a host population. Common vectors and hosts in cities include arthropods, rodents and bats [91]. Many EIDs are considered complex multi-host systems, where transmission is contingent on host competency and spatiotemporal variability in potential interactions [92]. The drivers behind occurrence or re-occurrence of EIDs are complex, yet most can be traced to some form of anthropogenic change or disruption $[93,94]$.

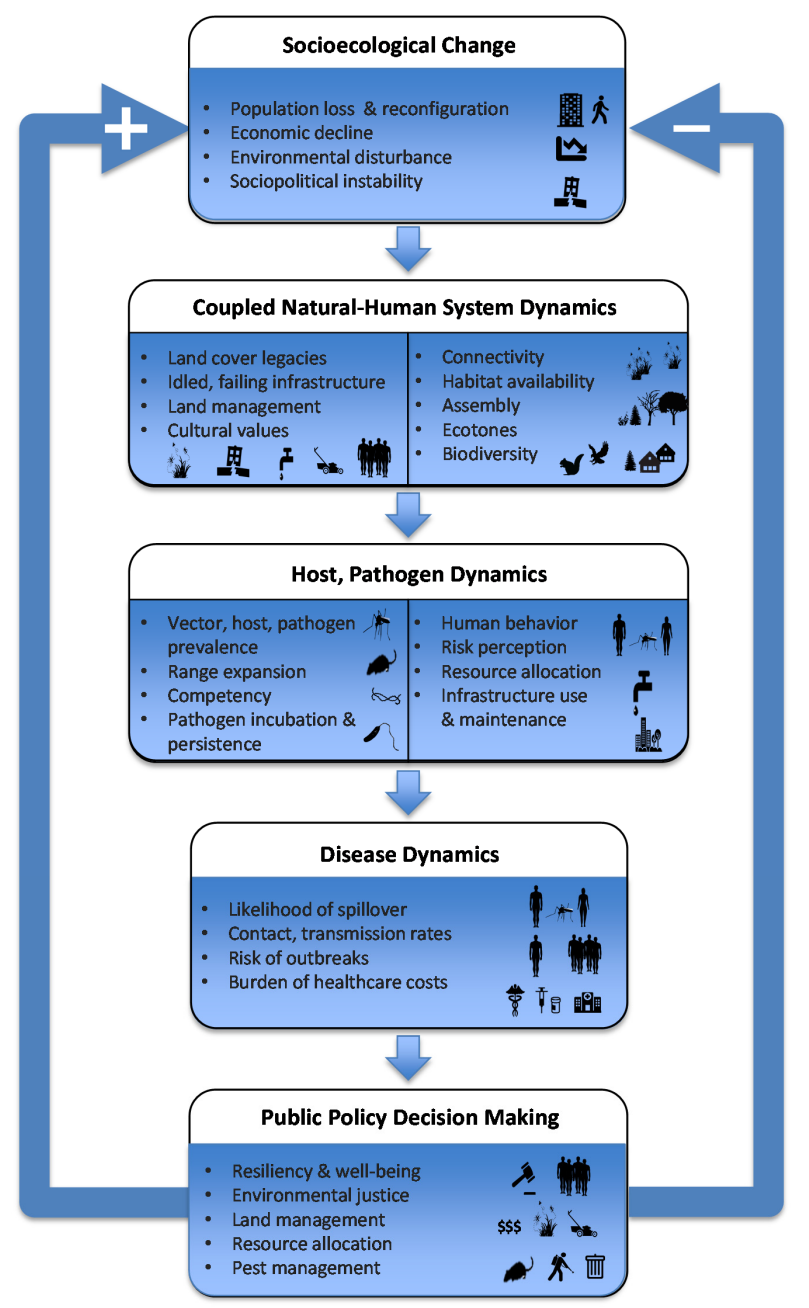

Figure 3. A socioecological framework conceptualizing feedbacks that can drive infectious disease dynamics in counter-urban environments. 


\subsection{Cities and Emerging Infectious Disease}

There is an assortment of conditions in cities that can interrupt host-pathogen dynamics and increase risk of zoonotic disease transmission [95]. Urbanized areas tend to elevate the threat of EIDs due to proximate socioenvironmental drivers of disease emergence including: Increased human movement and population density, air pollution, drinking water and sanitation system insecurity, limited access to health care services, as well as rapid land use and socioeconomic change [94-96]. By modifying transmission dynamics, these conditions can result in a cascade of interacting factors that disrupt the interplay between pathogens, hosts, and the environment [97]. A range of ecological mechanisms also have been linked to disease emergence in cities, including increased host range and community composition, availability of habitat for pathogens and vectors, as well as elevated contact rates [98]. However, few studies have been conducted on EIDs that extend beyond narrow geographic footprints and concerns of increasing human populations, as opposed to counter-urbanization $[34,99,100]$.

\subsection{Counter-Urbanization and Emerging Infectious Disease}

Though the effects of counter-urbanization on EID risk remain poorly studied [59,97], it is clear that disease dynamics can be altered by socioeconomic transitions that bring about behavioral modification alongside changes in land management and access to service-providing infrastructure. This suggests that counter-urbanization can spur disease emergence because occupancy becomes juxtaposed with abandonment, resulting in novel human-environment interfaces shaped by management release and infrastructure degradation [93]. Re-greening and community assembly also can allow for altered population dynamics, habitat shifts, and increased contact rates between humans and pathogens or pathogen vectors.

Studies of highly pathogenic avian influenza (HPAI) outbreaks across Vietnam illustrate how relevant socioecological transitions can drive disease emergence [101]. Peri-urban areas of Vietnam were found to be outbreak "hot spots" of HPAI, which is a poultry-associated disease linked to the H5N1 Avian influenza virus [101]. Peri-urban areas in Vietnam encompass socioecological transitions that elevate contact with commensal hosts, such as high levels of poultry diversity and livestock production shifting to residences, and patchwork configurations of land conversion and neglect [102]. The spatial coincidence of other factors associated with transitioning peri-urban areas include greater refuse, standing water, intensive land use and changes in land management $[101,102]$. Many of these conditions reflect the fluid demography, driven by high mobility (i.e., immigration and emigration), of peri-urban areas. Parallels can be readily drawn between peri-urban and counter-urban areas, which highlights the potential for abandonment and infrastructure decline to drive disease emergence (Table 1). It also indicates that elevated disease transmission risk is not an accident of time and place, but rather the product of identifiable change. 
Table 1. Selected examples of studies demonstrating mechanisms of socioecological transitions linked to conditions of counter-urbanization and shifts in emerging infectious diseases (EID) transmission.

\begin{tabular}{|c|c|c|c|c|c|c|c|}
\hline Disease & Pathogen and Type & Transmission & Main Host & Mechanism & Outcome & Study & Location \\
\hline \multicolumn{8}{|c|}{ Socioeconomic Transition } \\
\hline $\begin{array}{l}\text { American } \\
\text { Cutaneous } \\
\text { Leishmaniasis }\end{array}$ & $\begin{array}{l}\text { Protozoa: } \\
\text { Leishmania spp. }\end{array}$ & Vector; sandflies & $\begin{array}{l}\text { Wild and domestic } \\
\text { mammals, humans }\end{array}$ & $\begin{array}{l}\text { Poor housing conditions and } \\
\text { environmental sanitation, lack } \\
\text { of personal protective } \\
\text { measures, disruption of } \\
\text { services like trash collection } \\
\text { and sewage system, and } \\
\text { human migration }\end{array}$ & $\begin{array}{l}\text { Increased contact between hosts } \\
\text { and infected sand flies. }\end{array}$ & [103-105] & $\begin{array}{l}\text { North and South } \\
\text { America }\end{array}$ \\
\hline Toxocariasis & $\begin{array}{l}\text { Ascarid nematodes: } \\
\text { Toxocara canis and } \\
\text { Toxocara cati }\end{array}$ & $\begin{array}{l}\text { Indirect by contact } \\
\text { with soil or water } \\
\text { contaminated with } \\
\text { infected eggs }\end{array}$ & Dogs, cats, raccoons. & $\begin{array}{l}\text { Greater soil humidity, greater } \\
\text { feral animal movement. }\end{array}$ & $\begin{array}{l}\text { Faster incubation, increased } \\
\text { human-pathogen contact, } \\
\text { especially in neighborhoods } \\
\text { with poor irrigation systems } \\
\text { and that are prone to } \\
\text { flooding events. }\end{array}$ & {$[106,107]$} & Various \\
\hline \multicolumn{8}{|c|}{ Habitat Expansion } \\
\hline Giardiasis & $\begin{array}{l}\text { Protazoa: } \\
\text { Giardia lamblia }\end{array}$ & Indirect; waterborne & Humans, mammals & $\begin{array}{l}\text { Increased heterogeneity in } \\
\text { environment, edge effect } \\
\text { between vegetative habitat } \\
\text { and managed landscape, } \\
\text { more standing water }\end{array}$ & $\begin{array}{l}\text { Increased human-pathogen } \\
\text { contact }\end{array}$ & {$[108,109]$} & New York (US) \\
\hline $\begin{array}{l}\text { West Nile } \\
\text { Neuroinvasive } \\
\text { Disease, Dengue } \\
\text { Fever and } \\
\text { Chikungunya }\end{array}$ & $\begin{array}{l}\text { West Nile Virus, } \\
\text { Dengue Virus and } \\
\text { Chikungunya Virus }\end{array}$ & $\begin{array}{l}\text { Vector; mosquito } \\
\text { (Culex spp., } \\
\text { Anopheles spp.) }\end{array}$ & Mammals, birds & $\begin{array}{l}\text { Increased breeding habitat } \\
\text { through standing water in } \\
\text { abandoned tires, pools of } \\
\text { water associated with land } \\
\text { use change and demolition, } \\
\text { abandoned swimming pools }\end{array}$ & $\begin{array}{l}\text { Increased abundance of } \\
\text { mosquito vectors }\end{array}$ & {$[85,110-115]$} & North America \\
\hline Chagas Disease & $\begin{array}{l}\text { Parasite: } \\
\text { Trypanosoma cruzi }\end{array}$ & Vector; triatomine bug & $\begin{array}{l}\text { Wild and domestic } \\
\text { mammals, humans }\end{array}$ & $\begin{array}{l}\text { Forest fragmentation, an } \\
\text { increase in edge habitat, and } \\
\text { built infrastructure decay }\end{array}$ & $\begin{array}{l}\text { Increased vector abundance } \\
\text { and prevalence of parasite and } \\
\text { association between competent } \\
\text { host species diversity and } \\
\text { infection prevalence. }\end{array}$ & {$[65,116,117]$} & $\begin{array}{l}\text { South America, } \\
\text { Louisiana (US) }\end{array}$ \\
\hline
\end{tabular}


Table 1. Cont.

\begin{tabular}{|c|c|c|c|c|c|c|c|}
\hline Disease & Pathogen and Type & Transmission & Main Host & Mechanism & Outcome & Study & Location \\
\hline \multicolumn{8}{|c|}{ Contact Rate } \\
\hline Toxocariasis & $\begin{array}{l}\text { Ascarid nematodes: } \\
\text { Toxocara canis and } \\
\text { Toxocara cati }\end{array}$ & $\begin{array}{l}\text { Direct, indirect; } \\
\text { sometimes vector (flies) }\end{array}$ & $\begin{array}{l}\text { Domestic cats, dogs, } \\
\text { foxes, raccoons }\end{array}$ & $\begin{array}{l}\text { Playgrounds and sandboxes } \\
\text { in low income neighborhoods } \\
\text { with more feral dog and } \\
\text { cat populations }\end{array}$ & $\begin{array}{l}\text { Increased human-pathogen } \\
\text { contact, especially children }\end{array}$ & [118-121] & North America \\
\hline $\begin{array}{l}\text { West Nile } \\
\text { Neuroinvasive } \\
\text { Disease }\end{array}$ & Virus: flavivirus & $\begin{array}{l}\text { Vector-mosquito } \\
\text { (Culex spp.) }\end{array}$ & $\begin{array}{l}\text { Passerine birds, } \\
\text { mammals }\end{array}$ & $\begin{array}{l}\text { Anthropogenic land-use, } \\
\text { temperature, and housing } \\
\text { density favoring bird host } \\
\text { density increases }\end{array}$ & $\begin{array}{l}\text { Expansion of pathogen and } \\
\text { spillover into human } \\
\text { population. }\end{array}$ & [122] & Georgia (US) \\
\hline Leptospirosis & Bacteria: Leptiospira & $\begin{array}{l}\text { Direct; water, food or } \\
\text { soil contaminated with } \\
\text { infected animal urine }\end{array}$ & $\begin{array}{l}\text { Domestic and } \\
\text { feral mammals, } \\
\text { primarily rodents. }\end{array}$ & $\begin{array}{l}\text { Household environmental } \\
\text { factors such as residence in } \\
\text { flood-risk regions with open } \\
\text { sewers, proximity to } \\
\text { accumulated refuse, and } \\
\text { presence of chickens and rats. }\end{array}$ & $\begin{array}{l}\text { Increased prevalence in } \\
\text { neighborhoods especially those } \\
\text { with low socioeconomic status, } \\
\text { increased refuse, } \\
\text { standing water }\end{array}$ & {$[23,24]$} & Salvador, Brazil \\
\hline \multicolumn{8}{|c|}{ Connectivity and Species Movement } \\
\hline Plague & $\begin{array}{l}\text { Bacteria: } \\
\text { Yersina pestis }\end{array}$ & Direct; vector; flea & $\begin{array}{l}\text { Rodents including } \\
\text { prairie dogs, } \\
\text { peri-domestic animals }\end{array}$ & $\begin{array}{l}\text { Urban infringement of } \\
\text { vegetated and forested } \\
\text { environments and associated } \\
\text { increases in connectivity. }\end{array}$ & $\begin{array}{l}\text { Habitat expansion of pathogen } \\
\text { via species movement, } \\
\text { increased contact rate where } \\
\text { rodents more readily interact } \\
\text { with peri-domestic animals }\end{array}$ & {$[123,124]$} & US, Tanzania \\
\hline Rabies & Virus: Rhabdoviridae & Direct; saliva & $\begin{array}{l}\text { Mammals, raccoons, } \\
\text { dogs, bats, etc. }\end{array}$ & $\begin{array}{l}\text { Heterogeneous land use, } \\
\text { increases in green space } \\
\text { mixed with resource } \\
\text { clumping, and low human } \\
\text { population density }\end{array}$ & $\begin{array}{l}\text { Increased contact between } \\
\text { humans and infected hosts }\end{array}$ & {$[125-127]$} & North America \\
\hline
\end{tabular}




\subsection{Abandonment, Biodiversity and Emerging Infectious Disease}

It is often suggested that lower biodiversity in cities reduces ecosystem functioning, which in turn can disrupt ecosystem services and human well-being. High biodiversity is widely considered to be a favorable attribute because it can proffer greater functional redundancy $[128,129]$ and resilience [13,130], akin to portfolio financial management in which a diverse investment portfolio buffers against acute and destabilizing change [131]. Greater biodiversity may also increase the availability of valued services and resources [13,132-134]. Additionally, diversity may enhance capacity for adaptation $[131,135,136]$. For example, spatial heterogeneity can regulate flows and cycles of critical resources within ecosystems [137]. Lower diversity can, however, sometimes result in greater socioecological resilience and lower health risks [138-141].

Biodiversity should not be considered inherently beneficial, particularly when considered without regard to community composition. Abandoned areas and unmanaged greenspace have been found to harbor greater biodiversity than managed greenspace, but unmaintained areas can proffer greater harborage of commensal pests, including pathogen vectors [9,37,55]. Biodiversity thus can be an indicator of potential hazards rather than valued services. This sentiment is well reflected in management of abandoned or depopulated areas (e.g., mowing), which often aims to constrain rather than enhance diversity. Biodiversity may be deliberately suppressed when real or perceived risks exceed benefits to human health and well-being, and management interventions intended to reduce risk may iteratively reinforce (i.e., via species removal) rather than restore biodiversity.

Outcomes of abandonment could very well run contrary to increasingly contentious "biodiversity protects against disease" paradigm [104,142], which emphasizes the potential for a dilution effect (and the related phenomenon of zooprophylaxis) to lower transmission rates in humans by diverting transmission to other less competent hosts [100]. A dilution effect may occur if an increase in faunal diversity reduces the assemblage of transmission-competent hosts with non-competent hosts; thus the probability of vectors feeding on transmission-competent hosts declines and the abundance of infected vectors is also lowered [100]. This assumes, however, that the total abundance of vectors in a system does not vary. Critics of the "dilution effect" paradigm argue that the likelihood of dilution or amplification of disease transmission depends more on community composition than shifts in diversity $[100,143,144]$.

Zoonotic infectious disease emergence also can be viewed as a consequence of socioecological disruption of natural host-pathogen interactions (Figure 3), where relationships that regulate and stabilize relative abundance break down. From this, we can posit that heterogeneous or asymmetric community (re)assembly in times or areas of urban transition, particularly under conditions involving land use change, can foster disease emergence (Table 1). This is consistent with evidence suggesting that disease dynamics may be highly heterogeneous in both space and time, especially in multiple host and vector systems with varying competency levels $[100,145]$, where increased abundance of a particular host (or subset of hosts) may result in amplification rather than dilution $[59,145]$. The net effect of host diversity on disease emergence thus can become a function of vector versus host abundance [92]. Due to the potential complexity of these systems, individual relationships between vector(s) and host(s) become crucial to predicting outcomes [146], therefore diversity measures alone may not predict disease transmission as accurately as other measures of community composition in counter-urbanizing cities [100,147].

\subsection{Abandonment and Exposure Risk}

Exposure risk to vector-borne pathogens can parallel abandonment, which can shift the quality of local conditions to favor commensal pests and pathogen vectors [30,31,62]. Studies of rodents, for example, have found that larger populations are associated with conditions of abandonment, possibly due to greater availability of nesting and breeding sites [132,133]. A citywide investigation in New York City found that proximity to greenspace and prevalence of older or vacant housing units accurately predict rat sightings [142]. Similarly, comparisons of census records and land use 
to trapping-based estimates of rodent demography indicate that species diversity and densities are elevated in neighborhoods of New Orleans with concentrations of abandonment due to flooding following Hurricane Katrina [148]. Increased rodent species richness and abundance may permit the presence of greater pathogen diversity $[86,149,150]$ because different rodents harbor different pathogens, though some species can be co-infected with multiple pathogens including Leptospira, Babesia and Hantaviruses [150]. Because rodent-associated pathogens are generally spread by direct contact, inhalation and ingestion of rodent saliva, urine and feces [151], exposure risk can increase with the abundance and density of infected rodents, particularly when human-wildlife interfaces favor greater contact [152].

Exposure risk to mosquito-borne pathogens also likely parallels abandonment $[30,113,114]$. Microclimatic changes that arise with dereliction support common urban pest species including the Asian tiger mosquito (Aedes albopictus (Skuse)) and northern house mosquito (Culex pipiens L.) that are associated with the emergence of West Nile Virus, Dengue virus and Chikungunya virus across cities in the Eastern and Southern US [30]. Mosquito abundance is associated with availability of suitable habitat including vegetation, water-filled containers, and proximity to standing water [30]. Therefore abandoned areas, especially areas with vacant buildings in disrepair, can increase mosquito habitat availability. This is well illustrated by a study of Baltimore which found that mosquito breeding habitat availability (e.g., tires, roofless buildings, semi-permanent trash receptacles) is greater on blocks with more abandonment, and that the distribution of abandonment across Baltimore increases contact rates between remaining residents and mosquitos [114]. Similarly, abandoned swimming pools have been found to increase mosquito breeding habitat availability in New Orleans and California $[85,113]$.

The configuration of abandonment-separate from (or in addition to) factors contributing to habitat quality - can also elevate pathogen transmission and exposure risk. For instance, whether alone or in aggregate, abandonment can increase exposure risk through resource clumping. For hosts like rodents and mosquitos, vital resources (i.e., food, water, shelter, breeding sites) are more likely to be aggregated in abandoned areas than in surrounding urban or natural landscapes. Clumping of resources can elevate contact rates between pathogen vectors, promoting disease transmission [151,153]. A manipulation experiment involving raccoons illustrated that resource clumping resulted in greater contact rates, and that greater contact rates are associated with greater prevalence of endoparasites $[135,140,154]$. Pathogen transmission can also be elevated in areas with greater edge habitat between abandoned and occupied areas. For example, increased edge habitat amongst contrasting land uses in New York is associated with higher incidence of giardiasis [101], which is a common intestinal parasite infection caused by consumption of contaminated drinking water [108,155]. Similar spatial relationships involving ecotones, fragmentation and heterogeneous resource availability have been associated with other zoonotic infections, including Lyme disease (Table 1) [108,156].

\subsection{Infrastructure Decline and Exposure Risk}

According to the US Waterborne Disease and Outbreak Surveillance System, the largest challenge to the safety of drinking water in the US is the burden of maintaining infrastructure [157]. Public water systems supply drinking water to approximately 87 percent of US households, with higher rates in cities [158]. Operation and maintenance of water delivery systems, particularly systems with infrastructure built for high demand, requires municipalities to meet a minimum revenue threshold [8]. If the threshold is not met, cities may defer structural maintenance, which can result in leaking pipes, water breaks or power outages that can compound water insecurity over time. For example, between 2005 and 2013, New Orleans experienced nine city-wide boil water advisories (BWA), which are issued in accordance with the Safe Drinking Water Act due to drops in pressure, pipe bursts, or detection of pathogens or contaminants [157]. Another shrinking city, Cleveland, experienced nine localized BWAs between 2008 and 2013 [158]. Cities of comparable size with stable or growing populations had few if any BWAs during the same period $[157,158]$. 
Complications from declining water infrastructure are by no means limited to counter-urbanizing cities, but the consequences can be more pronounced. For example, in an effort to reduce expenses, the city of Flint-a rust belt city that has experienced a steady decline in population since the 1960s - switched water sources from the Detroit Water and Sewerage Department to the Flint River in 2014 [159]. The switch elevated levels of toxic heavy metals in the local water supply by increasing corrosion of the aging delivery system, spurring a public health crisis [159]. Following the switch, Flint residents experienced increased rates of lead poisoning and an outbreak of Legionnaire's disease, a water-borne bacterial infection linked to unsanitary water supply [160,161]. Similarly, disease outbreaks related to compromised water infrastructure have occurred in St. Bernard Parish (described below) and other shrinking cities across the US [157,162].

\section{A Tale of Two Neighborhoods: Health Risks of Managing Abandonment and Depopulation in New Orleans}

Two neighborhoods in the New Orleans metropolitan area-the Lower Ninth Ward and the adjacent section of St. Bernard Parish-clearly illustrate how management policies and decision-making that govern ecosystem dynamics can result in unanticipated public health hazards following population loss. The New Orleans metropolitan area lost an estimated 30 percent of its population between 1960 and 2005, and the 2010 US Census indicates that the population contracted by another $24 \%$ following Hurricane Katrina in 2005 [7]. One of the deadliest and most destructive hurricanes in US history, over 80\% of the urbanized East Bank of New Orleans was flooded following Hurricane Katrina, with some parts of the city under ten feet of water for weeks. Flooding affected approximately 228,000 occupied housing units ( $45 \%$ of the metropolitan total) [163]. The extent of damage, however, varied from neighborhood to neighborhood, and recovery has been equally patchy $[9,146,147]$. The Lower Ninth Ward and St. Bernard Parish were both redefined by population loss and abandonment resulting from severe flooding. In the Lower Ninth Ward, which lost $60 \%$ of its population between 2000 and 2010 and has a vacancy rate of $44 \%$, only $30 \%$ of housing has been recovered [7]. Almost 600 lots are currently under the management of the New Orleans Redevelopment Agency (NORA) $[7,9,164]$. Neighboring St. Bernard Parish (encompassing the municipalities of Arabi and Chalmette), which lost $85 \%$ of its population and has a $41 \%$ vacancy rate, has experienced a housing recovery rate of $51 \%$, with more than 1000 lots currently under parish management [7]. Despite these similarities, the parish line represents a sharp boundary between contrasting socioecological conditions and associated public health concerns.

The Lower Ninth Ward and neighboring St. Bernard Parish exemplify potential outcomes of land management policies intended to address abandonment [9]. To date, NORA has only mown publicly owned abandoned lots in the Lower Ninth Ward. More limited management of privately owned lots has given rise to a mosaic of maintained grasslands surrounded by ruderal vegetation dominated by invasive trees and shrubs like Chinese Tallow [9]. The prevalence of abandoned lots in the Lower Ninth Ward (with associated hazards of derelict housing, unmanaged vegetation, and illegal dumping) has created a haven for commensal pests and thus has increased the potential contact rate between remaining residents and pathogen vectors like rodents and mosquitos $[9,30,31,49,148]$. Regular maintenance of all abandoned lots in St. Bernard Parish has inhibited the emergence of opportunistic species, resulting in urban grasslands interspersed with a low density of rebuilt homes [165]. Consequently, St. Bernard Parish supports vegetation comparable to neighborhoods that did not experience severe flooding [9]. Though maintenance of abandoned property in St. Bernard Parish has suppressed EID risk factors [9,30,31], idled infrastructure has increased exposure risk to water-borne pathogens [25]. With a sharply reduced tax base, the parish has a financial burden of operating and maintaining infrastructure that far exceeds the demand of remaining households. The imbalance between demand and revenue has pressured the parish to reduce maintenance and use over time [166]. It is thought that this imbalance resulted in extended stagnation of drinking water lines, which can encourage growth of water-borne pathogens. Since 2011, the parish has experienced isolated cases of primary amebic meningoencephalitis (PAM), 
a fatal infection caused by Naegleria fowleri, a thermophilic water-borne amoeba [167]. PAM has been identified in the St. Bernard Parish drinking water distribution system, where poorly maintained water storage tanks are at risk of contamination, particularly during summer months [168].

\section{Implications}

\subsection{Socioecological Resilience and Environmental Justice}

Though it is often considered a term laden with unfavorable connotation, counter-urbanization is not necessarily an affliction of inexorable decline [66]. Cities can experience reversals, even after decades of population loss or disinvestment. For example, Baltimore has recently experienced demographic and economic gains, as has New Orleans since 2010. It is nonetheless imperative that urban planning and policies account for outcomes of counter-urbanization that can impart a lasting legacy on inhabitants, including health risks linked to ecological shifts and infrastructure deterioration $[19,34,169,170]$. Planning intended to reduce risk and ensure well-being of remaining residents should take careful stock of incongruencies with urban or suburban conditions, especially the nature of greenspace resulting from abandonment. Counter-urban systems present novel challenges that require distinct and sometimes innovative perspectives. Planning also should include consideration of potential non-linearities arising from socioecological feedbacks in order to avoid interventions that address short-term concerns but unintentionally generate long-term complications [170]. It thus could be advantageous to approach counter-urbanization as a coupled natural-human dynamic prone to unconventional epidemiological transitions and non-equilibrium behavior like pathogen outbreaks $[90,169,171]$.

Adopting a socioecological framework aligns with emerging theory on urban resilience (i.e., capacity to sustain shocks, like disasters, and maintain or rapidly return to functional capacity $[130-137,172,173])$, which provides a counterpoint to conventional models of urban planning. Unlike urban design theory and similar frameworks that focus on engineering resilience through modification of the environment to improve efficiency, precision and consistency [96,172-174], theory on socioecological resilience emphasizes the fluidity of demographic transitions, including stochastic shifts between alternative states of community composition driven by disruptions or disturbance [175]. Arguably, decision-makers would be better positioned to foster greater resilience by recognizing that population loss can be a vital factor that-alone or in conjunction with economic decline and ecological assembly-shapes the emergence and trajectory of challenging conditions (like abandonment) central to land management in cities [165].

For theory on socioecological resilience to meaningfully inform urban planning and policy, it must be discussed in close relation to environmental justice [9,49]. Concerns of environmental justice arise when communities do not "enjoy the same degree of protection from environmental and health hazards" or "equal access to the decision-making process to have a healthy environment in which to live, learn, and work" [176]. Many of the characteristic features of counter-urbanization, like abandonment, are disproportionally associated with low income and vulnerable populations (Figures 1 and 2). Abandonment is also associated with population density (Figure 2), which suggests that it affects a disproportionate number of inhabitants in counter-urbanizing cities. By intensifying existing socioecological asymmetries (e.g., differences in tree canopy cover) $[29,47-49,177,178]$, counter-urbanization can result in landscapes of escalating deficits in services like infrastructure delivery and environmental management. Absent of interventions intended to mitigate distributional inequalities, counter-urbanization can further marginalize affected areas and residents [49]. Thus addressing outcomes of counter-urbanization, including abandonment and accompanying health risks, falls under the broad umbrella of seeking environmental justice for affected communities [113,114]. One step towards achieving this goal is to identify at-risk communities by mapping risk factors, like blighted and abandoned greenspace (Figure 4), and to survey risk perception to better understand relationships between human behavior and potential health hazards. 


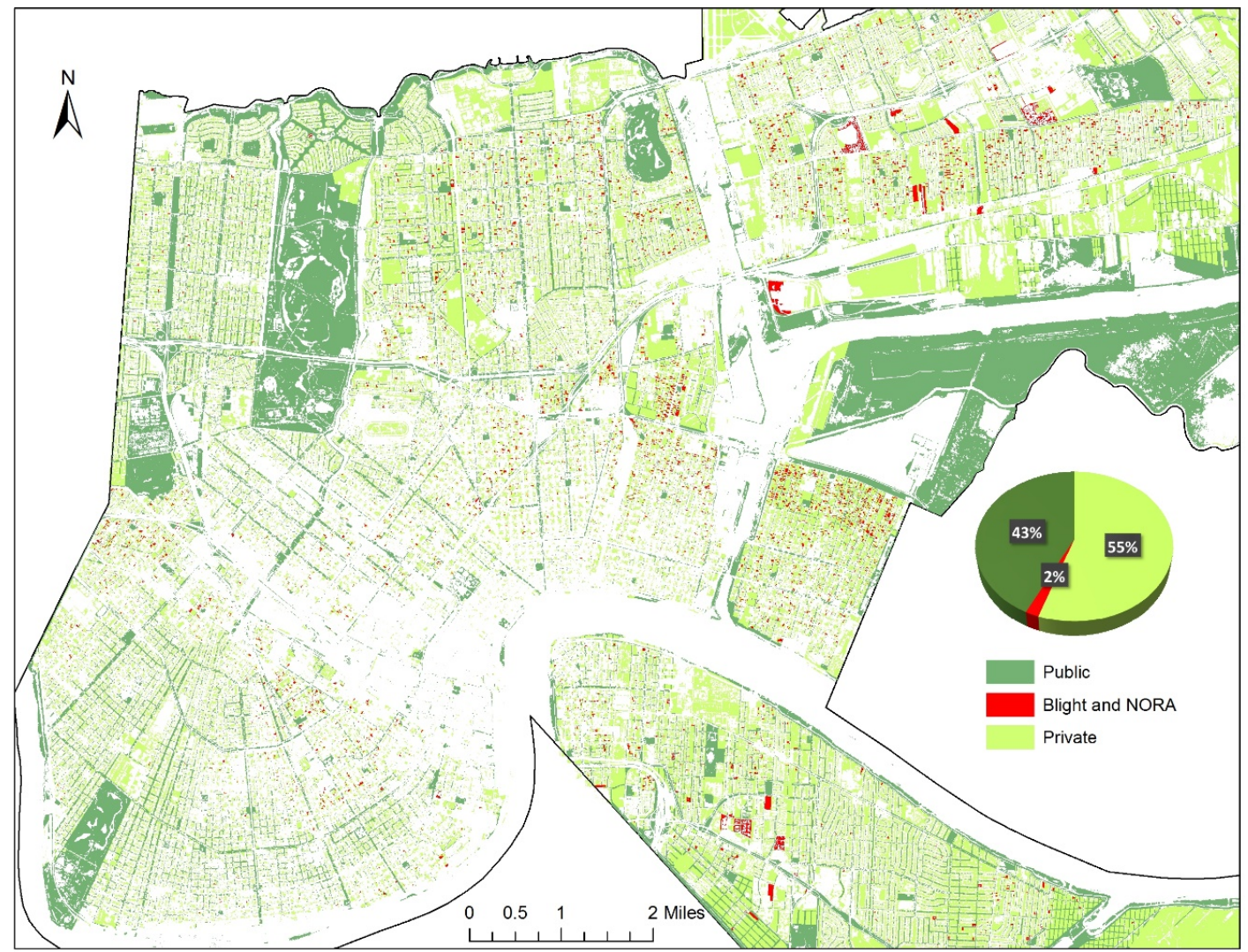

Figure 4. Vegetation cover by ownership status in New Orleans showing concentrations of abandonment in the Upper and Lower Ninth Wards and East New Orleans. Public lands include parks, medians, sidewalks, and cemeteries. Private land includes all lots not owned by a government entity, nor under code violation. Blight and New Orleans Redevelopment Authority (NORA) land include all properties managed by or cited by the City of New Orleans for overgrown and unmanaged vegetation. While these properties do not encompass all unmanaged and abandoned properties, they are representative of abandoned greenspace in the city.

\subsection{Planning for Decline?}

Addressing counter-urbanization requires the development and execution of a coherent plan that accounts for population loss, landscape management and infrastructure, often under conditions of reduced revenue. The struggle to determine and reconstitute utilities, infrastructure and greenspace with shifts in demand can be compounded by concerns about racial and socioeconomic disparities, social justice, and resistance to change in affected communities. In cities like New Orleans and Detroit, consideration has been given to the controversial concepts of deferring, removing or clustering development to create more densely populated neighborhoods with a smaller footprint requiring fewer services and utilities. [164]. Sometimes referred to as "right-sizing", clustering strategies can encompass elimination of redundant roads and other infrastructure, to discontinuation of whole neighborhoods [5]. For example, the Detroit Blight Committee proposed a campaign aimed at relocating residents and closing off remaining space to create an ecological reserve [5]. These plans have not been fully implemented, however, because depopulated areas still retain substantial numbers of people-often low income, minority residents—with strong cultural links to their neighborhoods [179]. Other notable examples of clustering campaigns include the widely condemned Urban Land Institute (ULI) proposal for recovery of New Orleans following Hurricane Katrina [164]. The ULI proposal, widely referred to as the "Green Dot" plan, identified areas of the city that could be transitioned to greenspace for stormwater mitigation and other purposes. Condemnation of the ULI proposal and other efforts to 
organize citywide redevelopment resulted in an uncoordinated, "laissez faire" housing recovery policy that permitted and sometimes incentivized rebuilding in low-lying, vulnerable areas [180].

Though clustering can be an extreme and often impractical solution, redistributing and managing resources are recurring challenges that need to be addressed in counter-urbanizing cities. On-demand infrastructure is one possible strategy to integrate flexibility into counter-urban systems [5]. Transfer of vacant and abandoned property to neighborhood residents also can help alleviate municipal expenses. For example, tax-reverted (i.e., abandoned) properties in Flint transferred to adjacent property owners were more likely to be managed and less likely to enter into tax foreclosure than properties sold at auction [164]. However, the success of this approach can vary. Comparisons of the analogous "Lot Next Door" program across New Orleans, for example, indicate that the approach is more effective in neighborhoods with higher rates of occupancy and higher mean household income [164]. Further exploration and study of similarly minded measures are certainly warranted. As counter-urbanization is neither a minor pattern nor a short-term departure from urban growth, ensuring well-being in shrinking cities will require the development of prospective approaches to land management that reduce risk associated with abandonment and population loss.

Acknowledgments: We thank the investigators of the $\mathrm{CNH}-\mathrm{New}$ Orleans project team for guidance on the development of this article. Funding for this work was made available from the Tulane-Xavier Center for Bioenvironmental Research and the National Science Foundation (BCS-1313703).

Author Contributions: Alexandra Gulachenski, Amy E. Lesen, and Michael J. Blum conceived and designed the review; Alexandra Gulachenski wrote the paper. Alexandra Gulachenski and Bruno M. Ghersi analyzed data; all authors edited the paper.

Conflicts of Interest: The authors declare no conflict of interest.

\section{Abbreviations}

The following abbreviations are used in this manuscript:

$\begin{array}{ll}\text { BWA } & \text { Boil Water Advisory } \\ \text { EID } & \text { Emerging Infectious Disease } \\ \text { HPAI } & \text { highly pathogenic avian influenza } \\ \text { NORA } & \text { New Orleans Redevelopment Authority } \\ \text { PAM } & \text { primary amebic meningoencephalitis } \\ \text { ULI } & \text { Urban Land Institute } \\ \text { US } & \text { United States of America }\end{array}$

\section{References}

1. Martinez-Fernandez, C.; Audirac, I.; Fol, S.; Cunningham-Sabot, E. Shrinking Cities: Urban Challenges of Globalization: Shrinking cities: urban challenges of globalization. Int. J. Urban Reg. Res. 2012, 36, 213-225. [CrossRef] [PubMed]

2. Pallagst, K.; Martinez-Fernandez, C.; Wiechmann, T. Shrinking Cities: An Emerging Planning Phenomenon. In Shrinking Cities: International Perspectives and Policy Implications; Routledge: New York, NY, USA, 2014.

3. Beyer, E.; Hagemann, A.; Rieniets, T.; Oswalt, P. Atlas of Shrinking Cities; Hatje Cantz Publishers: Berlin, Germany, 2006.

4. Kabisch, S.; Haase, A.; Haase, D. Beyond Growth-Urban Development in Shrinking Cities as a Challenge for Modeling Approaches. Available online: http://www.iemss.org/iemss2006/sessions/all.html (accessed on 16 May 2016).

5. Hollander, J.B.; Pallagst, K.; Schwarz, T.; Popper, F.J. Planning shrinking cities. Prog. Plan. 2009, 72, 223-232.

6. Burkholder, S. The New Ecology of Vacancy: Rethinking Land Use in Shrinking Cities. Sustainability 2012, 4, 1154-1172. [CrossRef]

7. U.S Census Bureau American FactFinder. Available online: http://factfinder.census.gov/faces/nav/jsf/ pages/index.xhtml (accessed on 1 December 2015).

8. Iverson Nassauer, J.; Raskin, J. Urban vacancy and land use legacies: A frontier for urban ecological research, design, and planning. Landsc. Urban Plan. 2014, 125, 245-253. [CrossRef] 
9. Lewis, J.A.; Zipperer, W.C.; Hazen, R.; Blum, M.J.; Elmqvist, T.; Henrik, E. Socioecological responses of urban vegetation to catastrophic flooding and land abandonment in New Orleans following Hurricane Katrina, 2015. Ecosphere. In review.

10. Ramalho, C.E.; Hobbs, R.J. Time for a change: dynamic urban ecology. Trends Ecol. Evol. 2012, 27, $179-188$. [CrossRef] [PubMed]

11. Levy, M.Z.; Barbu, C.M.; Castillo-Neyra, R.; Quispe-Machaca, V.R.; Ancca-Juarez, J.; Escalante-Mejia, P.; Borrini-Mayori, K.; Niemierko, M.; Mabud, T.S.; Behrman, J.R.; et al. Urbanization, land tenure security and vector-borne Chagas disease. Proc. R. Soc. Lond. B Biol. Sci. 2014. [CrossRef] [PubMed]

12. Pickett, S.T.A.; Cadenasso, M.L.; Grove, J.M.; Boone, C.G.; Groffman, P.M.; Irwin, E.; Kaushal, S.S.; Marshall, V.; McGrath, B.P.; Nilon, C.H.; et al. Urban ecological systems: Scientific foundations and a decade of progress. J. Environ. Manag. 2011, 92, 331-362. [CrossRef] [PubMed]

13. Wallace, D.; Wallace, R. Urban systems during disasters: factors for resilience. Ecol. Soc. 2008, 13. Article 18.

14. Kinzig, A.P.; Warren, P.; Martin, C.; Hope, D.; Katti, M. The effects of human socioeconomic status and cultural characteristics on urban patterns of biodiversity. Ecol. Soc. 2005, 10. Article 23.

15. McDonnell, M.; Pickett, S.T. Ecosystem Structure and Function along Urban-Rural Gradients: An unexploited Opportunity for Ecology. Ecology 1990, 71, 1232-1237. [CrossRef]

16. Shochat, E.; Warren, P.S.; Faeth, S.H.; McIntyre, N.E.; Hope, D. From patterns to emerging processes in mechanistic urban ecology. Trends Ecol. Evol. 2006, 21, 186-191. [CrossRef] [PubMed]

17. Godefroid, S.; Koedam, N. Urban plant species patterns are highly driven by density and function of built-up areas. Landsc. Ecol. 2007, 22, 1227-1239. [CrossRef]

18. Wu, J.; Loucks, O.L. From Balance of Nature to Hierarchical Patch Dynamics: A Paradigm Shift in Ecology. Q. Rev. Biol. 1995, 70, 439-466. [CrossRef]

19. Wu, J.; Jenerette, G.D.; David, J.L. Linking land-use change with ecosystem processes: A hierarchical patch dynamic model. In Integrated Land Use and Environmental Models; Guhathakurta, F.S., Ed.; Springer: Berlin/Heidelberg, Germany, 2003; pp. 99-119.

20. Grove, J.M.; William, R.B., Jr. A social ecology approach and applications of urban ecosystem and landscape analyses: A case study of Baltimore, Maryland. Urban Ecosyst. 1997, 1, 259-275. [CrossRef]

21. Grove, M.; Cadenasso, M.; Pickett, S.; Machlis, G.; Burch, W.R.; Burch, W.R. Expanding the Landscape: applying Patch Dynamics to Social-Ecological Systems. In The Baltimore School of Urban Ecology: Space, Scale, and Time for the Study of Cities; Yale University Press: New Haven, CT, USA, 2015; pp. 38-76.

22. Alberti, M. Advances in Urban Ecology Integrating Humans and Ecological Processes in Urban Ecosystems; Springer: New York, NY, USA, 2008.

23. Liu, J.; Dietz, T.; Carpenter, S.R.; Folke, C.; Alberti, M.; Redman, C.L.; Schneider, S.H.; Ostrom, E.; Pell, A.N.; Lubchenco, J.; et al. Coupled human and natural systems. AMBIO J. Hum. Environ. 2007, 36, 639-649. [CrossRef]

24. Kremer, P.; Hamstead, Z.A.; McPhearson, T. A social-ecological assessment of vacant lots in New York City. Landsc. Urban Plan. 2013, 120, 218-233. [CrossRef]

25. Faschan, A.; Hoffer, R.; Daly, L.; Parish, S.B. Hurricane Katrina Impacts on Wastewater Infrastructure-Lessons Learned. Proc. Water Environ. Fed. 2007, 2007, 2859-2873. [CrossRef]

26. Garvin, E.; Branas, C.; Keddem, S.; Sellman, J.; Cannuscio, C. More Than Just An Eyesore: Local Insights And Solutions on Vacant Land And Urban Health. J. Urban Health Bull. N. Y. Acad. Med. 2013, 90, 412-426. [CrossRef] [PubMed]

27. Escobedo, F.; Varela, S.; Zhao, M.; Wagner, J.E.; Zipperer, W. Analyzing the efficacy of subtropical urban forests in offsetting carbon emissions from cities. Environ. Sci. Policy 2010, 13, 362-372. [CrossRef]

28. Douglas, I. Urban ecology and urban ecosystems: Understanding the links to human health and well-being. Curr. Opin. Environ. Sustain. 2012, 4, 385-392. [CrossRef]

29. Lyytimäki, J.; Sipilä, M. Hopping on one leg-The challenge of ecosystem disservices for urban green management. Urban For. Urban Green. 2009, 8, 309-315. [CrossRef]

30. Becker, B.; Leisnham, P.; LaDeau, S.; LaDeau, S. A Tale of Two City Blocks: Differences in Immature and Adult Mosquito Abundances between Socioeconomically Different Urban Blocks in Baltimore (Maryland, USA). Int. J. Environ. Res. Public. Health 2014, 11, 3256-3270. [CrossRef] [PubMed]

31. LaDeau, S.L.; Allan, B.F.; Leisnham, P.T.; Levy, M.Z. The ecological foundations of transmission potential and vector-borne disease in urban landscapes. Funct. Ecol. 2015, 29, 889-901. [CrossRef] [PubMed] 
32. Mackenstedt, U.; Jenkins, D.; Romig, T. The role of wildlife in the transmission of parasitic zoonoses in peri-urban and urban areas. Int. J. Parasitol. Parasites Wildl. 2015, 4, 71-79. [CrossRef] [PubMed]

33. Forman, R.T.T.; Godron, M. Patches and Structural Components for A Landscape Ecology. BioScience 1981, 31, 733-740.

34. Grimm, N.B.; Grove, J.G.; Pickett, S.T.A.; Redman, C.L. Integrated Approaches to Long-Term Studies of Urban Ecological Systems. BioScience 2000, 50, 571-584. [CrossRef]

35. Grove, J.M.; Locke, D.H.; O'Neil-Dunne, J.P. An ecology of prestige in New York City: Examining the relationships among population density, socio-economic status, group identity, and residential canopy cover. Environ. Manage. 2014, 54, 402-419. [CrossRef] [PubMed]

36. Alberti, M. The Effects of Urban Patterns on Ecosystem Function. Int. Reg. Sci. Rev. 2005, 28, 168-192. [CrossRef]

37. Haase, D.; Seppelt, R.; Haase, A. Land use impacts of demographic change-lessons from Eastern German urban regions. In Use of Landscape Sciences for the Assessment of Environmental Security; Petrosillo, I., Müller, F., Jones, K.B., Zurlini, G., Krauze, K., Victorov, S., Li, B.-L., Kepner, W.G., Eds.; Springer Netherlands: Dordrecht, The Netherlands, 2007; pp. 329-344.

38. Burkman, C.E.; Gardiner, M.M. Spider assemblages within greenspaces of a deindustrialized urban landscape. Urban Ecosyst. 2014, 18, 793-818. [CrossRef]

39. Steenberg, J.W.N.; Millward, A.A.; Duinker, P.N.; Nowak, D.J.; Robinson, P.J. Neighbourhood-scale urban forest ecosystem classification. J. Environ. Manag. 2015, 163, 134-145. [CrossRef] [PubMed]

40. Seto, K.; Parnell, S.; Elmqvist, T. A Global Outlook on Urbanization. In Urbanization, Biodiversity and Ecosystem Services: Challenges and Opportunities: A Global Assessment; Springer: New York, NY, USA, 2013.

41. Bruno, J.F.; Stachowicz, J.J.; Bertness, M.D. Inclusion of facilitation into ecological theory. Trends Ecol. Evol. 2003, 18, 119-125. [CrossRef]

42. Webb, C.O.; Ackerly, D.D.; McPeek, M.A.; Donoghue, M.J. Phylogenies and Community Ecology. Annu. Rev. Ecol. Syst. 2002, 33, 475-505. [CrossRef]

43. Freudenberg, N.; Glaea, S.; Vlahov, D. Cities and the Health of the Public; Freudenberg, N., Glaea, S., Vlahov, D., Eds.; 1st ed.; Vanderbilt University Press: Nashville, TN, USA, 2006.

44. Swan, C.M.; Pickett, S.T.; Szlavecz, K.; Warren, P.; Willey, K.T. Biodiversity and Community Composition in Urban Ecosystems: Coupled Human, Spatial, and Metacommunity Processes. Available online: https:// www.researchgate.net/profile/Christopher_Swan3/publication/267857001_Biodiversity_and_Community_ Composition_in_Urban_Ecosystems_Coupled_Human_Spatial_and_Metacommunity_Processes/links / 54ad6e5d0cf2213c5fe3faa5.pdf (accessed on 17 May 2016).

45. Pickett, S.T.; Cadenasso, M.L.; Grove, J.M.; Groffman, P.M.; Band, L.E.; Boone, C.G.; Burch, W.R.; Grimmond, C.S.B.; Hom, J.; Jenkins, J.C. Beyond urban legends: An emerging framework of urban ecology, as illustrated by the Baltimore ecosystem study. BioScience 2008, 58, 139-150. [CrossRef]

46. Nowak, D.J.; Dwyer, J.F. Understanding the benefits and costs of urban forest ecosystems. In Urban and Community Forestry in the Northeast; Kuser, J.E., Ed.; Springer Netherlands: Dordrecht, The Netherlands, 2007; pp. 25-46.

47. Schwarz, K.; Fragkias, M.; Boone, C.G.; Zhou, W.; McHale, M.; Grove, J.M.; O’Neil-Dunne, J.; McFadden, J.P.; Buckley, G.L.; Childers, D.; et al. Trees grow on money: Urban tree canopy cover and environmental justice. PLoS ONE 2015, 10, e0122051. [CrossRef] [PubMed]

48. Berland, A.; Schwarz, K.; Herrmann, D.L.; Hopton, M.E. How environmental justice patterns are shaped by place: Terrain and tree canopy in cincinnati, Ohio, USA. Cities Environ. CATE 2015, 8. Article 1.

49. Ernstson, H. The social production of ecosystem services: A framework for studying environmental justice and ecological complexity in urbanized landscapes. Landsc. Urban Plan. 2013, 109, 7-17. [CrossRef]

50. Heynen, N. Green Urban Political Ecologies: Toward a Better Understanding of Inner-City Environmental Change. Environ. Plan. A 2006, 38, 499-516. [CrossRef]

51. Heynen, N.C. The scalar production of injustice within the urban forest. Antipode 2003, 35, 980-998. [CrossRef]

52. Pham, T.-T.-H.; Apparicio, P.; Séguin, A.-M.; Landry, S.; Gagnon, M. Spatial distribution of vegetation in Montreal: An uneven distribution or environmental inequity? Landsc. Urban Plan. 2012, 107, $214-224$. [CrossRef] 
53. Bigsby, K.M.; McHale, M.R.; Hess, G.R. Urban Morphology Drives the Homogenization of Tree Cover in Baltimore, MD, and Raleigh, NC. Ecosystems 2013, 17, 212-227. [CrossRef]

54. Brazel, A.; Selover, N.; Vose, R.; Heisler, G. The tale of two climates-Baltimore and Phoenix urban LTER sites. Clim. Res. 2000, 15, 123-135. [CrossRef]

55. Shuster, W.D.; Dadio, S.; Drohan, P.; Losco, R.; Shaffer, J. Residential demolition and its impact on vacant lot hydrology: Implications for the management of stormwater and sewer system overflows. Landsc. Urban Plan. 2014, 125, 48-56. [CrossRef]

56. Faeth, S.H.; Bang, C. Saari Urban biodiversity: Patterns and mechanisms. Ann. N. Y. Acad. Sci. 2011, 1223, 69-81. [CrossRef] [PubMed]

57. Pándi, I.; Penksza, K.; Botta-Dukát, Z.; Kröel-Dulay, G. People move but cultivated plants stay: Abandoned farmsteads support the persistence and spread of alien plants. Biodivers. Conserv. 2014, 23, 1289-1302. [CrossRef]

58. Otero, I.; Marull, J.; Tello, E.; Diana, G.L.; Pons, M.; Coll, F.; Boada, M. Land abandonment, landscape, and biodiversity: Questioning the restorative character of the forest transition in the Mediterranean. Ecol. Soc. 2015, 20. [CrossRef]

59. Speldewinde, P.C.; Slaney, D.; Weinstein, P. Is restoring an ecosystem good for your health? Sci. Total Environ. 2015, 502, 276-279. [CrossRef] [PubMed]

60. Benayas, J.M.R.; Newton, A.C.; Diaz, A.; Bullock, J.M. Enhancement of Biodiversity and Ecosystem Services by Ecological Restoration: A Meta-Analysis. Science 2009, 325, 1121-1124. [CrossRef] [PubMed]

61. Dewar, T.; Manning, J. Introduction: The City after Abandonment. In The City after Abandonment; University of Pennsylvania Press: Philadelphia, PA, USA, 2012; pp. 133-150.

62. Haase, D. Shrinking Cities, Biodiversity and Ecosystem Services. In Urbanization, Biodiversity and Ecosystem Services: Challenges and Opportunities: A Global Assessment; Springer: New York, NY, USA, 2013.

63. Foo, K.; Martin, D. The Production of Urban Vacant Land: Relational Placemaking in Boston, Massachusetts Neighborhoods. Cities 2013, 35, 156-163. [CrossRef]

64. Brownlow, A. An archaeology of fear and environmental change in Philadelphia. Geoforum 2006, 37, $227-245$. [CrossRef]

65. Gottdenker, N.L. Effects of Anthropogenic Land Use Change on the Ecology of the Chagas Disease Agent Trypanosoma Cruzi, University of Georgia, 2009. Available online: http://purl.galileo.usg.edu/uga_etd/ gottdenker_nicole_1_200908_phd (accessed on 17 January 2016).

66. Berry, B.J.L. Urbanization and Counterurbanization in the United States. Ann. Am. Acad. Pol. Soc. Sci. 1980, 451, 13-20. [CrossRef]

67. Tauzer, E. The Phytogeography of Vacant Lots in Baltimore, MD, USA: A Test of Island Biogeography. Available online: http://www.caryinstitute.org/sites/default/files/public/reprints/Tauzer_2009_REU.pdf (accessed on 16 May 2016).

68. Winter, M.; Schweiger, O.; Klotz, S.; Nentwig, W.; Andriopoulos, P.; Arianoutsou, M.; Basnou, C.; Delipetrou, P.; Didžiulis, V.; Hejda, M.; et al. Plant extinctions and introductions lead to phylogenetic and taxonomic homogenization of the European flora. Proc. Natl. Acad. Sci. USA 2009, 106, 21721-21725. [CrossRef] [PubMed]

69. Alonso, D.; Etienne, R.; Mckane, A. The merits of neutral theory. Trends Ecol. Evol. 2006, 21, 451-457. [CrossRef] [PubMed]

70. Bertness, M.D.; Leonard, G. The Role of Positive Interactions in Communities: Lessons from Intertidal Habitats. Ecology 1997, 78, 1976-1989. [CrossRef]

71. Connor, E.F.; Simberloff, D. The Assembly of Species Communities: Chance or Competition? Ecology 1979, 60, 1132-1140. [CrossRef]

72. Diamond, J.M. Assembly of species communities. In Ecology and Evolution of Communities; Cody, M., Diamond, J.M., Eds.; The belknap press of Harvard Univerisity: Cambridge, UK, 1975; pp. 342-444.

73. Gotelli, N.J.; McCabe, D.J. Species Co-Occurrence: A Meta-Analysis of J.M. Diamond's Assembly Rules Model. Ecology 2002, 83, 2091-2096. [CrossRef]

74. Hubbell, S.P. The Unified Neutral Theory of Biodiversity and Biogeography; Princeton University Press: Princeton, NJ, USA, 2001.

75. Weiher, E.; Keddy, P. Ecological Assembly Rules: Perspectives, Advances, Retreats; Cambridge University Press: Cambridge, UK, 1999. 
76. Freudenburg, W.R.; Frickel, S.; Gramling, R. Beyond the Nature/Society Divide: Learning to Think about a Mountain. Sociol. Forum 1995, 10, 361-392. [CrossRef]

77. Grimm, N.B.; Redman, C.L. Approaches to the study of urban ecosystems: The case of Central Arizona-Phoenix. Urban Ecosyst. 2004, 7, 199-213. [CrossRef]

78. Kowarik, I.; Körner, S.; NetLibrary, I. Wild Urban Woodlands New Perspectives for Urban Forestry; Springer: Berlin, Germany; New York, NY, USA, 2005.

79. Burkman, C.E.; Gardiner, M.M. Urban greenspace composition and landscape context influence natural enemy community composition and function. Biol. Control 2014, 75, 58-67. [CrossRef]

80. Hanks, L.; Denno, R.F. Natural Enemies and Plant Water Relations Influence the Distribution of An Armored Scale Insect. Ecology 1993, 74, 1081-1091. [CrossRef]

81. Concepción, E.D.; OBrist, M.K. Impacts of urban sprawl on species richness of plants, butterflies, gastropods and birds: not only built-up area matters. Urban Ecosyst. 2016, 19, 225-242. [CrossRef]

82. Paula, M.; Shrewsbury, M.J.R. Evaluation of Components of Vegetational Texture for Predicting Azalea Lace Bug, Stephanitis pyrioides (Heteroptera: Tingidae), Abundance in Managed Landscapes. Environ. Entomol. 2000, 29, 919-926.

83. Burkman, C.E. The Influence of Habitat Management and Landscape on Spider Assemblages within Urban Greenspaces of Cleveland, Ohio. Master's Thesis, The Ohio State University, Columbus, OH, USA, 2013.

84. Caillouët, K.A.; Michaels, S.R.; Xiong, X.; Foppa, I.; Wesson, D.M. Increase in West Nile neuroinvasive disease after hurricane Katrina. Emerg. Infect. Dis. 2008, 14, 804. [CrossRef] [PubMed]

85. Caillouët, K.A.; Carlson, J.C.; Wesson, D.; Jordan, F. Colonization of abandoned swimming pools by larval mosquitoes and their predators following Hurricane Katrina. J. Vector Ecol. 2008, 33, 166-172. [CrossRef]

86. Himsworth, C.G.; Parsons, K.L.; Jardine, C.; Patrick, D.M. Rats, cities, people, and pathogens: A systematic review and narrative synthesis of literature regarding the ecology of rat-associated zoonoses in urban centers. Vector Borne Zoonotic Dis. 2013, 13, 349-359. [CrossRef] [PubMed]

87. Keating, D. Redevelopment of Vacant Land in the Blighted Neighborhoods of Cleveland, Ohio, Resulting from the Housing Foreclosure Crisis. J. Regen. Renew. 2010, 4, 39-52.

88. Margulis, H.L. Rat Fields, Neighborhood Sanitation, and Rat Complaints in Newark, New Jersey. Geogr. Rev. 1977, 67, 221. [CrossRef]

89. Feng, A.Y.T.; Himsworth, C.G. The secret life of the city rat: a review of the ecology of urban Norway and black rats (Rattus norvegicus and Rattus rattus). Urban Ecosyst. 2013, 17, 149-162. [CrossRef]

90. Wilcox, B.A.; Gubler, D.J. Disease ecology and the global emergence of zoonotic pathogens. Environ. Health Prev. Med. 2005, 10, 263-272. [CrossRef] [PubMed]

91. Kilpatrick, A.M.; Randolph, S.E. Drivers, dynamics, and control of emerging vector-borne zoonotic diseases. Lancet 2012, 380, 1946-1955. [CrossRef]

92. Dobson, A. Population dynamics of pathogens with multiple host species. Am. Nat. 2004, 164, S64-S78. [CrossRef] [PubMed]

93. Daszak, P.; Cunningham, A.A.; Hyatt, A.D. Anthropogenic environmental change and the emergence of infectious diseases in wildlife. Acta Trop. 2001, 78, 103-116. [CrossRef]

94. Engering, A.; Hogerwerf, L.; Slingenbergh, J. Pathogen-host-environment interplay and disease emergence. Emerg. Microbes Infect. 2013, 2, e5. [CrossRef] [PubMed]

95. Brearley, G.; Rhodes, J.; Bradley, A.; Baxter, G.; Seabrook, L.; Lunney, D.; Liu, Y.; McAlpine, C. Wildlife disease prevalence in human-modified landscapes. Biol. Rev. Camb. Philos. Soc. 2013, 88, 427-442. [CrossRef] [PubMed]

96. Finucane, M.L.; Fox, J.; Saksena, S.; Spencer, J.H. A Conceptual Framework for Analyzing Social-Ecological Models of Emerging Infectious Diseases. In Understanding Society and Natural Resources; Manfredo, M.J., Vaske, J.J., Rechkemmer, A., Duke, E.A., Eds.; Springer Netherlands: Dordrecht, The Netherlands, 2014; pp. 93-109.

97. Patz, J.A.; Daszak, P.; Tabor, G.M.; Aguirre, A.A.; Pearl, M.; Epstein, J.; Wolfe, N.D.; Kilpatrick, A.M.; Foufopoulos, J.; Molyneux, D.; et al. Unhealthy Landscapes: Policy Recommendations on Land Use Change and Infectious Disease Emergence. Environ. Health Perspect. 2004, 112, 1092-1098. [CrossRef] [PubMed]

98. Gottdenker, N.L.; Streicker, D.G. Anthropogenic land use change and infectious diseases: A review of the evidence. EcoHealth 2014, 11, 619-632. [CrossRef] [PubMed] 
99. Bradley, C.A.; Altizer, S. Urbanization and the ecology of wildlife diseases. Trends Ecol. Evol. 2007, 22, 95-102. [CrossRef] [PubMed]

100. Randolph, S.E.; Dobson, A.D.M. Pangloss revisited: A critique of the dilution effect and the biodiversity-buffers-disease paradigm. Parasitology 2012, 139, 847-863. [CrossRef] [PubMed]

101. Saksena, S.; Fox, J.; Epprecht, M.; Tran, C.C.; Castrence, M.; Nong, D.; Spencer, J.; Nguyen, L.; Finucane, M.; Vien, T.D.; et al. Role of Urbanization, Land-Use Diversity, and Livestock Intensification in Zoonotic Emerging Infectious Diseases; East-West Center: Honolulu, HI, USA, 2014.

102. McGee, T. The emergence of desakota regions in Asia: Expanding a hypothesis. In The Extended Metropolis: Settlement Transition in Asia; University of Hawaii Press: Honolulu, HI, USA, 1991; pp. 3-25.

103. Alvar, J.; Yactayo, S.; Bern, C. Leishmaniasis and poverty. Trends Parasitol. 2006, 22, 552-557. [CrossRef] [PubMed]

104. Chaves, L.F.; Cohen, J.M.; Pascual, M.; Wilson, M.L. Social Exclusion Modifies Climate and Deforestation Impacts on a Vector-Borne Disease. PLoS Negl. Trop. Dis. 2008, 2, e176. [CrossRef] [PubMed]

105. Costa, C.H.N.; Werneck, G.L.; Rodrigues, L.; Santos, M.V.; Araújo, I.B.; Moura, L.S.; Moreira, S.; Gomes, R.B.B.; Lima, S.S. Household structure and urban services: Neglected targets in the control of visceral leishmaniasis. Ann. Trop. Med. Parasitol. 2005, 99, 229-236. [CrossRef] [PubMed]

106. Beers, S.A.; Novosil'ts ev, G.I.; Mel'nikova, L.I. The role of the water factor in the dissemination of Toxocara eggs and the spread of toxocariasis in a megalopolis. Parazitologiia 1998, 33, 129-135.

107. Paquet-Durand, I.; Hernández, J.; Dolz, G.; Zuñiga, J.J.R.; Schnieder, T.; Epe, C. Prevalence of Toxocara spp., Toxascaris leonina and ancylostomidae in public parks and beaches in different climate zones of Costa Rica. Acta Trop. 2007, 104, 30-37. [CrossRef] [PubMed]

108. Walsh, M.G. Forest Fragmentation and Risk of Giardiasis in New York State. EcoHealth 2013, 10, 405-414. [CrossRef] [PubMed]

109. Giardiasis Surveillance-United States, 2009-2010. Available online: http://www.cdc.gov/mmwr/preview/ mmwrhtml/ss6105a2.htm (accessed on 1 April 2016).

110. Allan, B.F.; Langerhans, R.B.; Ryberg, W.A.; Landesman, W.J.; Griffin, N.W.; Katz, R.S.; Oberle, B.J.; Schutzenhofer, M.R.; Smyth, K.N.; de St. Maurice, A.; et al. Ecological correlates of risk and incidence of West Nile virus in the United States. Oecologia 2009, 158, 699-708. [CrossRef] [PubMed]

111. Bradley, C.A.; Gibbs, S.E.J.; Altizer, S. Urban land use predicts West Nile virus exposure in songbirds. Ecol. Appl. 2008, 18, 1083-1092. [CrossRef] [PubMed]

112. Johnson, B.J.; Munafo, K.; Shappell, L.; Tsipoura, N.; Robson, M.; Ehrenfeld, J.; Sukhdeo, M.V. The roles of mosquito and bird communities on the prevalence of West Nile virus in urban wetland and residential habitats. Urban Ecosyst. 2012, 15, 513-531. [CrossRef] [PubMed]

113. Reisen, W.K.; Takahashi, R.M.; Carroll, B.D.; Quiring, R. Delinquent mortgages, neglected swimming pools, and West Nile virus, California. Emerg. Infect. Dis. 2008, 14, 1747-1749. [CrossRef] [PubMed]

114. LaDeau, S.L.; Leisnham, P.T.; Biehler, D.; Bodner, D. Higher mosquito production in low-income neighborhoods of Baltimore and Washington, DC: Understanding ecological drivers and mosquito-borne disease risk in temperate cities. Int. J. Environ. Res. Public. Health 2013, 10, 1505-1526. [CrossRef] [PubMed]

115. Weterings, R.; Umponstira, C.; Buckley, H.L. Container-breeding mosquitoes and predator community dynamics along an urban-forest gradient: The effects of habitat type and isolation. Basic Appl. Ecol. 2014, 15, 486-495. [CrossRef]

116. Diaz, J.H. Chagas disease in the United States: A cause for concern in Louisiana? J. La. State Med. Soc. 2007, 159, 21-23, 25-29. [PubMed]

117. Ramsey, J.M.; Alvear, A.L.; Ordoñez, R.; Muñoz, G.; Garcia, A.; Lopez, R.; Leyva, R. Risk factors associated with house infestation by the Chagas disease vector Triatoma pallidipennis in Cuernavaca metropolitan area, Mexico. Med. Vet. Entomol. 2005, 19, 219-228. [CrossRef] [PubMed]

118. Mizgajska, H. Eggs of Toxocara spp. in the environment and their public health implications. J. Helminthol. 2001, 75, 147-151. [PubMed]

119. Despommier, D. Toxocariasis: Clinical Aspects, Epidemiology, Medical Ecology, and Molecular Aspects. Clin. Microbiol. Rev. 2003, 16, 265-272. [CrossRef] [PubMed]

120. Macpherson, C.N.L. The epidemiology and public health importance of toxocariasis: A zoonosis of global importance. Int. J. Parasitol. 2013, 43, 999-1008. [CrossRef] [PubMed] 
121. Hotez, P.J. Neglected Infections of Poverty in the United States of America. PLoS Negl. Trop. Dis. 2008, 2, e256. [CrossRef] [PubMed]

122. Gibbs, S.E.J.; Wimberly, M.C.; Madden, M.; Masour, J.; Yabsley, M.J.; Stallknecht, D.E. Factors affecting the geographic distribution of West Nile virus in Georgia, USA: 2002-2004. Vector Borne Zoonotic Dis. 2006, 6, 73-82. [CrossRef] [PubMed]

123. Gage, K.L.; Dennis, D.T.; Orloski, K.A.; Ettestad, P.; Brown, T.L.; Reynolds, P.J.; Pape, W.J.; Fritz, C.L.; Carter, L.G.; Stein, J.D. Cases of cat-associated human plague in the Western US, 1977-1998. Clin. Infect. Dis. 2000, 30, 893-900. [CrossRef] [PubMed]

124. Stenseth, N.C.; Atshabar, B.B.; Begon, M.; Belmain, S.R.; Bertherat, E.; Carniel, E.; Gage, K.L.; Leirs, H.; Rahalison, L. Plague: Past, present, and future. PLoS Med. 2008, 5, e3. [CrossRef] [PubMed]

125. Jones, M.E.; Curns, A.T.; Krebs, J.W.; Childs, J.E. Environmental and human demographic features associated with epizootic raccoon rabies in Maryland, Pennsylvania, and Virginia. J. Wildl. Dis. 2003, 39, 869-874. [CrossRef] [PubMed]

126. Duke, J.E. Land Use and Urbanization Patterns in An Established Enzootic Raccoon Rabies Area; Auburn University: Atlanta, GA, USA, 2012.

127. Duke, J.E.; Blanton, J.D.; Ivey, M.; Rupprecht, C. Modeling enzootic raccoon rabies from land use patterns-Georgia (USA) 2006-2010. F1000Research 2014, 2. [CrossRef] [PubMed]

128. Levin, S.A. Ecosystems and the biosphere as complex adaptive systems. Ecosystems 1998, 1, 431-436. [CrossRef]

129. Tilman, D.; Knops, J.; Wedin, D.; Reich, P.; Ritchie, M.; Siemann, E. The influence of functional diversity and composition on ecosystem processes. Science 1997, 277, 1300-1302. [CrossRef]

130. Gunderson, L. Ecology and society: Ecological and human community resilience in response to natural disasters. Ecol. Soc. 2010, 15. Article 18.

131. Folke, C. Resilience: The emergence of a perspective for social-ecological systems analyses. Glob. Environ. Chang. 2006, 16, 253-267. [CrossRef]

132. Adger, W.N. Social and ecological resilience: Are they related? Prog. Hum. Geogr. 2000, 24, 347-364. [CrossRef]

133. Holling, C.S. Understanding the complexity of economic, ecological, and social systems. Ecosystems 2001, 4, 390-405. [CrossRef]

134. Holling, C.S. Resilience and Stability of Ecological Systems. Annu. Rev. Ecol. Syst. 1973, 4, 1-23. [CrossRef]

135. Pickett, S.T.A.; Cadenasso, M.L.; Grove, J.M. Resilient cities: Meaning, models, and metaphor for integrating the ecological, socio-economic, and planning realms. Landsc. Urban Plan. 2004, 69, 369-384. [CrossRef]

136. Redman, C.L. Resilience theory in archaeology. Am. Anthropol. 2005, 107, 70-77. [CrossRef]

137. Pickett, S.T.A.; Cadenasso, M.L.; Grove, J.M.; Nilon, C.H.; Pouyat, R.V.; Zipperer, W.C.; Costanza, R. Urban ecological systems: Linking terrestrial ecological, physical, and socioeconomic components of metropolitan areas. Annu. Rev. Ecol. Syst. 2001, 32, 127-157. [CrossRef]

138. Putnam, R.D. Bowling Alone: The Collapse and Revival of American Community; Simon and Schuster: New York, NY, USA, 2001.

139. Putnam, R.D. E pluribus unum: Diversity and community in the twenty-first century the 2006 Johan Skytte Prize Lecture. Scand. Polit. Stud. 2007, 30, 137-174. [CrossRef]

140. Leitki, N. Does Diversity Erode Social Cohesion? Social Capital and Race in British Neighbourhoods. Polit. Stud. 2008, 56, 99-126. [CrossRef]

141. Stolle, D.; Soroka, S.; Johnston, R. When Does Diversity Erode Trust? Neighborhood Diversity, Interpersonal Trust and the Mediating Effect of Social Interactions. Polit. Stud. 2008, 56, 57-75. [CrossRef]

142. Walsh, M.G. Rat sightings in New York City are associated with neighborhood sociodemographics, housing characteristics, and proximity to open public space. PeerJ 2014, 2, e533. [CrossRef] [PubMed]

143. Begon, M. Effects of Host Diversity on Disease Dynamics. In Infectious Disease Ecology: Effects of Ecosystems on Disease and of Disease on Ecosystems; Princeton University Press: Princeton, NJ, USA, 2010.

144. Roche, B.; Dobson, A.P.; Guegan, J.-F.; Rohani, P. Linking community and disease ecology: The impact of biodiversity on pathogen transmission. Philos. Trans. R. Soc. B 2012, 367, 2807-2813. [CrossRef] [PubMed]

145. Roche, B.; Guégan, J.-F. Ecosystem dynamics, biological diversity and emerging infectious diseases. C. R. Biol. 2011, 334, 385-392. [CrossRef] [PubMed] 
146. Keesing, F.; Holt, R.D.; Ostfeld, R.S. Effects of species diversity on disease risk: Effects of species diversity on disease risk. Ecol. Lett. 2006, 9, 485-498. [CrossRef] [PubMed]

147. Wood, C.L.; Lafferty, K.D.; DeLeo, G.; Young, H.S.; Hudson, P.J.; Kuris, A.M. Does biodiversity protect humans against infectious disease? Ecology 2014, 95, 817-832. [CrossRef] [PubMed]

148. Blum, M.J. Diversity and Disease in a Post-Trauma Urban Landscape; Tulane University: New Orleans, LA, USA, 2014.

149. Plyusnina, A.; Krajinović, L.C.; Margaletić, J.; Niemimaa, J.; Nemirov, K.; Lundkvist, Å.; Markotić, A.; Miletić-Medved, M.; Avšič-Županc, T.; Henttonen, H.; et al. Genetic evidence for the presence of two distinct hantaviruses associated with Apodemus mice in Croatia and analysis of local strains. J. Med. Virol. 2011, 83, 108-114. [CrossRef] [PubMed]

150. Tadin, A.; Turk, N.; Korva, M.; Margaletić, J.; Beck, R.; Vucelja, M.; Habuš, J.; Svoboda, P.; Županc, T.A.; Henttonen, H.; et al. Multiple Co-infections of Rodents with Hantaviruses, Leptospira, and Babesia in Croatia. Vector Borne Zoonotic Dis. 2012, 12, 388-392. [CrossRef] [PubMed]

151. Riley, S.; Serieys, L.E.K.; Moriarty, J. Infectious disease and contaminats in urban wildlife: Unseen and often overlooked threats. In Urban Wildlife Conservation: Theory and Practice; McCleery, R.A., Moorman, C.E., Peterson, M.N., Eds.; Springer US: Boston, MA, USA, 2014.

152. Linard, C.; Lamarque, P.; Heyman, P.; Ducoffre, G.; Luyasu, V.; Tersago, K.; Vanwambeke, S.O.; Lambin, E.F. Determinants of the geographic distribution of Puumala virus and Lyme borreliosis infections in Belgium. Int. J. Health Geogr. 2007, 6, 15. [CrossRef] [PubMed]

153. Becker, D.J.; Streicker, D.G.; Altizer, S. Linking anthropogenic resources to wildlife-pathogen dynamics: A review and meta-analysis. Ecol. Lett. 2015, 18, 483-495. [CrossRef] [PubMed]

154. Wright, A.N.; Gompper, M.E. Altered parasite assemblages in raccoons in response to manipulated resource availability. Oecologia 2005, 144, 148-156. [CrossRef] [PubMed]

155. Haque, R. Human Intestinal Parasites. J. Health Popul. Nutr. 2007, 25, 387-391. [PubMed]

156. Ogrzewalska, M.; Uezu, A.; Jenkins, C.N.; Labruna, M.B. Effect of Forest Fragmentation on Tick Infestations of Birds and Tick Infection Rates by Rickettsia in the Atlantic Forest of Brazil. EcoHealth 2011, 8, 320-331. [CrossRef] [PubMed]

157. Choffnes, E.R.; Rapporteurs, A.M. Global Issues in Water, Sanitation, and Health: Workshop Summary; National Academies Press: Washington, DC, USA, 2009.

158. Rainey, R. Boil Water Advisories May Be Common in New Orleans, but the Risk Is Real, Experts Say. Available online: http://www.nola.com/politics/index.ssf/2013/03/boil_water_advisories_may_be_c.html (accessed on 16 May 2016).

159. Lin, J.C.F.; Rutter, J.; Park, H. Events That Led to Flint's Water Crisis. Available online: http://www.nytimes. com/interactive/2016/01/21/us/flint-lead-water-timeline.html?_r=0 (accessed on 16 May 2016).

160. Smith, M.; Goodnough, A. Michigan Officials Defend Handling of Legionnaires' Disease Outbreak in Flint. N. Y. Times 2016. Available online: http:/ /www.nytimes.com/2016/02/10/us/michigan-officials-defendhandling-of-legionnaires-disease-outbreak-in-flint.html?_r=0 (accessed on 16 May 2016).

161. Michigan Department of Health and Human Services. Summary of Legionellosis Outbreak-Genesee County, June 2014-March 2015. Available online: http:/ / www.michigan.gov/documents/mdhhs/Genesee_Co_ Legionnaires_Disease_Investigation_Ex_Summary_FINAL_510722_7.pdf (accessed on 16 May 2016).

162. Beer, K.D.; Gargano, J.W.; Roberts, V.A.; Hill, V.R.; Garrison, L.E.; Kutty, P.; Hilborn, E.D.; Wade, T.J.; Fullerton, K.E.; Yoder, J.S. Surveillance for waterborne disease outbreaks associated with drinking water-United States, 2011-2012. Morb. Mortal. Wkly. Rep. 2015, 64, 842-848. [CrossRef]

163. The Brookings Institute. New Orleans after the Storm: Lessons from the Past, a Plan for the Future; The Brookings Institute: Washington, DC, USA, 2005.

164. Ehrehfeucht, R.; Nelson, M. Recovery in a shrinking city: Challenges to rightsizing post- Katrina New Orleans. In The City After Abandonment; City in the twenty-first century book series; University of Pennsylvania Press: Philadelphia, PA, USA, 2012.

165. Gotham, K.F.; Blum, M.; Campanella, R. Toward a new normal: Trauma, diversity, and the New Orleans urban long-term research area exploratory (ULTRA-Ex) project. Cities Environ. CATE 2014, 7, 4.

166. City Business Staff Reports, St. Bernard Prez: Smaller Population Straining Parish'S Budget; New Orleans CityBusiness: New Orleans, LA, USA, 2010. 
167. Alexander-Bloch, B. St. Bernard Water System Tests Positive for Rare Brain-Eating Amoeba, CDC Confirms; Times-Picayune New Orleans: New Orleans, LA, USA, 2013.

168. Yoder, J.S.; Straif-Bourgeois, S.; Roy, S.L.; Moore, T.A.; Visvesvara, G.S.; Ratard, R.C.; Hill, V.R.; Wilson, J.D.; Linscott, A.J.; Crager, R.; et al. Primary amebic meningoencephalitis deaths associated with sinus irrigation using contaminated tap water. Clin. Infect. Dis. 2012, 55, 79-85. [CrossRef] [PubMed]

169. Wilcox, B.A.; Colwell, R.R. Emerging and Reemerging Infectious Diseases: Biocomplexity as an Interdisciplinary Paradigm. EcoHealth 2005, 2, 244-257. [CrossRef]

170. Waltner-Toews, D. An ecosystem approach to health and its applications to tropical and emerging diseases. Cad. Saúde Pública 2001, 17 Suppl., 7-22. [CrossRef] [PubMed]

171. Gallopín, G.C. Linkages between vulnerability, resilience, and adaptive capacity. Glob. Environ. Chang. 2006, 16, 293-303. [CrossRef]

172. Gotham, K.F.; Campanella, R. Coupled vulnerability and resilience: The dynamics of cross-scale interactions in post-Katrina New Orleans. Ecol. Soc. 2011, 16. [CrossRef]

173. Meerow, S.; Newell, J.P.; Stults, M. Defining urban resilience: A review. Landsc. Urban Plan. 2016, 147, 38-49. [CrossRef]

174. Holling, C.S. Surprise for Science, Resilience for Ecosystems, and Incentives for People. Ecol. Appl. 1996, 6, 733-735. [CrossRef]

175. Beisner, D.T.H. Alternative Stable States in Ecology. Front. Ecol. Environ. 2003, 1, 376-382. [CrossRef]

176. Environemental Justice. Available online: https://www.epa.gov/sites/production/files/widgets/ ejscreenwidget.html (accessed on 4 April 2016).

177. Sanders, R. Some determinants of urban forest structure. Elsevier 1984, 8, 13-27. [CrossRef]

178. Pataki, D.E.; Carreiro, M.M.; Cherrier, J.; Grulke, N.E.; Jennings, V.; Pincetl, S.; Pouyat, R.V.; Whitlow, T.H.; Zipperer, W.C. Coupling biogeochemical cycles in urban environments: Ecosystem services, green solutions, and misconceptions. Front. Ecol. Environ. 2011, 9, 27-36. [CrossRef]

179. Blanco, H.; Alberti, M.; Olshansky, R.; Chang, S.; Wheeler, S.M.; Randolph, J.; London, J.B.; Hollander, J.B.; Pallagst, K.M.; Schwarz, T.; et al. Shaken, shrinking, hot, impoverished and informal: Emerging research agendas in planning. Prog. Plan. 2009, 72, 195-250. [CrossRef]

180. Campanella, R. The Great Footprint Debate, Updated; Times-Picayune New Orleans: New Orleans, LA, USA, 2015. 